\title{
Petrology, physicochemical and thermal analyses of selected cretaceous coals from the Benue Trough Basin in Nigeria
}

\author{
S. A. Akinyemi ${ }^{1}$ (D) O. F. Adebayo ${ }^{1}$ - B. B. Nyakuma ${ }^{2}$ - A. K. Adegoke ${ }^{1}$ - O. A. Aturamu ${ }^{1}$ - O. A. OlaOlorun ${ }^{1}$. \\ A. Adetunji ${ }^{3}$ J. C. Hower ${ }^{4}$ - M. M. Hood ${ }^{4}$ - A. Jauro ${ }^{5}$
}

Received: 1 January 2019/Revised: 15 December 2019/Accepted: 18 February 2020/Published online: 2 March 2020

(C) The Author(s) 2020

\begin{abstract}
Abundant coal resources that were previously neglected due to a crude oil boom need revitalisation and integration into the national electricity mix to address the energy demands of the Nigerian population. Selected coal samples from the Benue Trough sedimentary basin in Nigeria were examined by various techniques, including proximate and ultimate analyses, organic petrography, Fourier transform infrared ray spectroscopy, and thermogravimetric analysis. Based on vitrinite reflectance, the Lafia-Obi (OLB), Garin Maiganga (GMG), Imiegba (IMG), and Okaba (OKB) coals are classified as subbituminous, while the Lamja1 (LMJ1), Lamja2 (LMJ2) and Chikila (CHK) coals are high volatile B bituminous. The Enugu (ENG) coal is on the boundary between subbituminous and high volatile C bituminous. Organic petrographic results indicate vitrinite and fusinite contents steadily increase from the Lower Benue Trough coals to the Upper Benue Trough coals, while semifusinite and total mineral contents follow a reverse pattern. Thermal decomposition occurred in three stages, i.e., drying, devolatilization, and coke formation above $700{ }^{\circ} \mathrm{C}$; and the coal reactivity follows the following order, ENG $>\mathrm{IMG}>\mathrm{IGH}>\mathrm{CHK}>\mathrm{LMJ}>\mathrm{OKB}>\mathrm{GMG}>\mathrm{LFB}$. The higher temperatures (above $900{ }^{\circ} \mathrm{C}$ ) are required to decompose the coals for efficient energy recovery. The LMJ1, LMJ2, OLB, CHK, GMG, and OKB coals can be exploited for electricity power generation. However, the Imeagha and Enugu coals are best suitable for both cement and power generation.
\end{abstract}

Keywords Petrology $\cdot$ Thermal analysis $\cdot$ Cretaceous coal $\cdot$ Benue Trough, Nigeria

S. A. Akinyemi

segun.akinyemi@eksu.edu.ng

1 Department of Geology, Ekiti State University, P. M. B 5363, Ado Ekiti, Ekiti State, Nigeria

2 School of Chemical and Energy Engineering, Universiti Teknologi Malaysia, Skudai, Malaysia

3 Department of Geology, Obafemi Awolowo University, P.M. B 013, Ile Ife, Osun State, Nigeria

4 Centre for Applied Energy Research, University of Kentucky, Kentucky, USA

5 National Centre for Petroleum Research and Development (NCPRD), Abubakar Tafawa Balewa University, Bauchi, Nigeria

\section{Introduction}

The inadequate supply of electricity in Nigeria is hindering socio-economic growth and sustainable development, despite the nation's abundant energy resources. There exists a robust relationship between socio-economic development and access to electricity in the nations around the world (Kanagawa and Nakata 2008). In spite of this, the electricity generation capacity of Nigeria has declined by $60 \%$ owing to years of negligence by successive regimes (Aliyu et al. 2013; Oodo and Zou 2009). As such, only 40\% of Nigeria's citizens have access to electricity, with varying degree of power failure, systematic power cuts, and low voltage (Aniefiok et al. 2013; Sambo 2009; Vincent-Akpu 2012). Moreover, Nigeria's gas-dominated electricity grid consistently breaks down, primarily due to insufficient gas 
supply. This has been exacerbated by gas pipeline vandalism linked with resource-control militancy in the oilproducing Niger Delta region (Iwayemi 2008). Therefore, there is an urgent need to diversify the national energy mix and protect power-generation infrastructure.

Coal utilization for electric power generation can potentially address the problems of energy diversification and self-sufficiency in Nigeria. As a primary source of energy, coal is an essential part of the global energy mix, currently accounting for $38 \%$ of global electricity generation (Khan et al. 2018). Coal has significantly contributed to the socio-economic growth and sustainable development of many countries across the globe (Kettanah and Eble 2017), despite growing concerns about environmental degradation, global warming, and climate change (McGlade and Ekins 2015; Meinshausen et al. 2009). According to the United States Energy Information Administration (IEA-OECD 2002), the world's total coal reserves are estimated at $926 \mathrm{Gt}$ (billion tonnes), with the significant deposits located in China, USA, India, Australia, Indonesia, Russia, and Germany (Speight 2012).

In Nigeria, the proven reserves of coal are about $639 \mathrm{Mt}$ (million tonnes), whereas the inferred reserves are $2.75 \mathrm{Gt}$ (Adedosu et al. 2007; Chukwu et al. 2016; Ohimain 2014). According to Chukwu et al. (2016), Nigerian coals consist of $12 \%$ lignite, $49 \%$ subbituminous, and 39\% bituminous, which are primarily located in the Benue Trough sedimentary basin. However, recent exploration efforts have revealed the discovery of commercial quantities of coal in 14 of the 36 Nigerian States, including Abia, Adamawa, Anambra, Bauchi, Benue, Cross-River, Delta, Ebonyi, Edo, Gombe, Imo, Kogi, Nasarawa, and Plateau States of Nigeria (Ohimain 2014). There are 22 known coalfields in Nigeria, and only Okaba, Okpara, Onyeama, and Orukpa are currently operational as depicted in Fig. 1. Obwette, Ribadu, and Ogbete were historically mined (Oboirien et al. 2018; Ohimain 2014; Sambo 2009).

The latest discovery of new deposits has renewed interest in coal utilization for electricity power generation in Nigeria (Nyakuma et al. 2018; Ohimain 2014; Ryemshak and Jauro 2013). However, there is limited research on the assessment of the power generation potential of some newly discovered coal deposits, and also on their organic petrology and fuel characteristics. Earlier research on Nigerian coals has centred on their metallurgical applications (Akpabio et al. 2008; Jauro and Chukwu 2011) along with its rheological and proximate (Ryemshak and Jauro 2013), mineralogical (Adedosu et al. 2007; Ogala et al. 2012), and geochemical characteristics (Jauro et al. 2007; Olajire et al. 2007). However, more information is required for the efficient design, operation, and maintenance of coal-fired power plants in Nigeria. Hence, extensive research is needed to examine the fuel characteristics of Nigerian coals. The aim of this research is to investigate the petrography, rank classification, and thermal fuel characteristics of some selected coal deposits from the Benue Trough Basin, with a view to appraise their energy recovery and electricity generation potentials in Nigeria.

\section{Geological setting of Benue Trough}

The Benue Trough is a linear, intracratonic and graben basin, $800 \mathrm{~km}$ long and $90 \mathrm{~km}$ wide on the average in eastern Nigeria (Ogungbesan and Akaegbobi 2011; Fatoye and Gideon 2013). The Benue Trough is a linear NE-SW trending Anticlinorium stretching from the Chad Basin in the North to the Gulf of Guinea through Niger Delta in the South (Avbovbo 1980). The Benue Trough basin is filled by approximately $6000 \mathrm{~m}$ thick alternating marine, paralic, and continental sediments of Cretaceous-Tertiary ages predating the mid-Santonian age. The sediments were compressed, deformed, folded, faulted, and uplifted in several places, and produced over 100 anticlines and synclines. The Benue Trough is geographically subdivided into Lower, Middle, and Upper Benue Trough (Whiteman 1982) (Fig. 2). These subdivisions are broadly based on differences in the physiographic and lithostratigraphic nomenclature (Sonibare et al. 2008).

The comprehensive reports of the geological and stratigraphic progressions in the Benue Trough are highlighted in the literature (Ayinla et al. 2017; Obaje et al. 2004; Offodile 1976; Petters 1982; Yandoka et al. 2016). The upper section of the Benue trough is split at the northeastern side into the basins around Gongola and Yola (Fig. 2). In these basins, the Albian Bima sandstone unconformably overlies the basement and is conformably overlain by the Cenomanian transitional or coastal Yolde Formation that characterises the start of marine incursion into the Upper Benue Trough (UBT). In the Gongola basin, the laterally equivalent Gongila and Pindiga Formations correlate with the Yolde Formation. The formations were intruded by marine infiltration into the Upper Benue Trough during the later Cenomanian-Turonian-Santonian periods. In the Yola Basin, the Dukul, Jessu, and Sekuliye Formations exist along with carbonaceous Lamja Sandstones and Numanha shales. The Upper CenomanianTuronian-Santonian (CTS) equivalents are the Gongila and Pindiga Formations. The Upper CTS deposits in the Yola Basin are lithologically and paleoenvironmentally similar to the Gongola Basin, except for the Lamja Sandstone, which is dominated by marine sandstone lithology. The post-folding sediments are represented by the continental coal-bearing Campano-Maastrichtian-age Gombe sandstone and the Paleogene Kerri-Kerri Formation. 


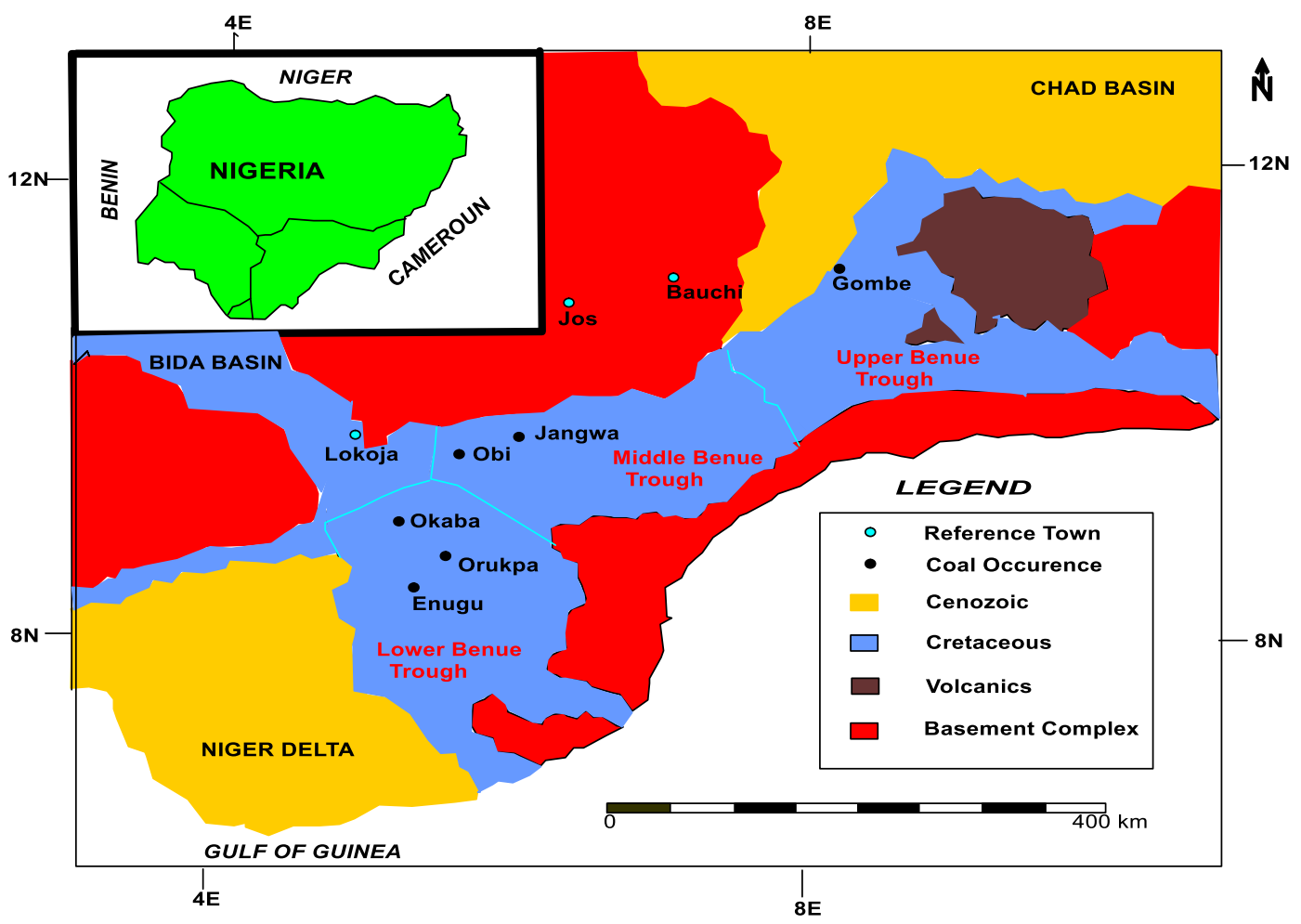

Fig. 1 Location of major coal occurrences in the Benue Trough of Nigeria (Obaje et al. 1999)

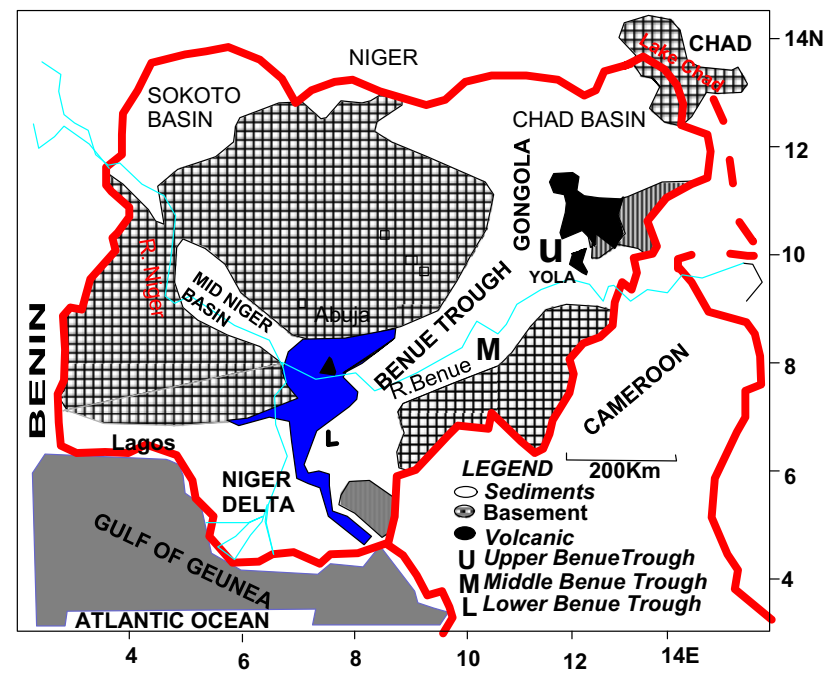

Fig. 2 Geological map of Nigeria showing the Benue Trough (Jauro et al. 2007)

In the Middle Benue Trough (MBT), around Lafia-Obi, six Upper Cretaceous lithogenic formations consists of stratigraphic successions (Fig. 3), including Albian Arufu, Uomba, and the Gboko Formations commonly called the Asu River Group (Offodile 1976). In turn, these were overlain by the Cenomanian Keana, Awe, and the Cenomanian-Turonian Ezeaku Formations. The late Turonian/ early Santonian coal-bearing Awgu Formation lies

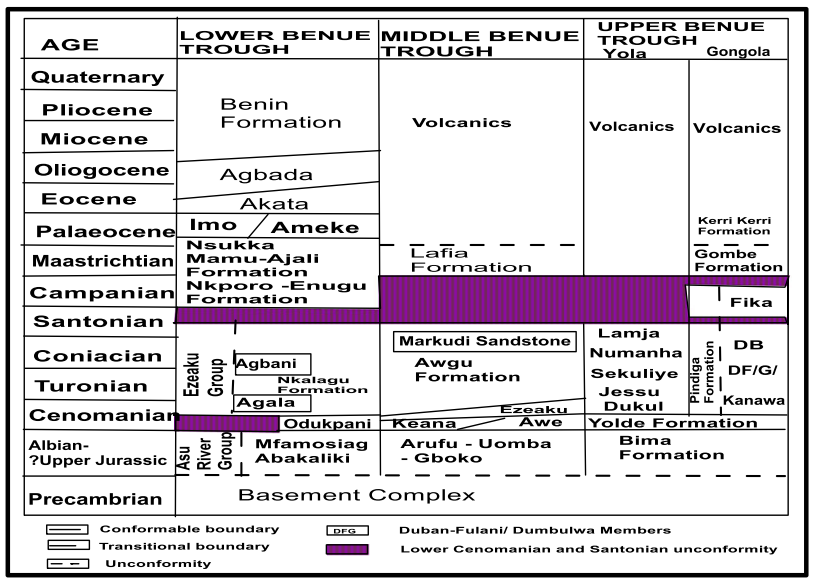

Fig. 3 Stratigraphic succession of Benue Trough (Abubakar et al. 2006)

conformably over the Ezeaku Formation. The post-folding Campanian-Maastrichtian Lafia Formation terminated the sedimentation in the Middle Benue Trough and was followed by Paleogene volcanic activity.

In the Lower Benue Trough (LBT), the oldest geological formation overlying the basement is the Albian Asu River Group. This marine-influenced formation consists of dark coloured fine-grained sandstones and siltstones, overlain by shales and limestones (Offodile 1980). Next in succession is the Cross River Group, which comprises the Odukpani, 
Agala, Nkalagu, and Agbani Formations. However, the only acknowledged marine Cenomanian rocks in the margins of the basin occurred in the Odukpani Formation, which consists of limestones and calcareous sandstones. The Cross River Group was succeeded by the Santonianage major folds concurrent with depositional episodes. The Nkporo shales and deposition of Maastrichtian Mamu Formation coal measure are evidence of marine incursion in the Basin. This also includes the enigmatically bedded sandstones and shales of the Ajali and Nsukka Formations, respectively. Palaeocene deposits overlie on the older formations.

The Benue Trough is believed to have been initiated in the early Cretaceous time forming as a split from the Central West African basement during the separation of African and South American continents (break up of Gondwanaland). This break up was followed by the separation of these continents, opening of the south Atlantic, and growth of the Mid Atlantic Ridge (King 1950; Olade, 1975; Benkhelil 1989). Recent evidence from petrographic studies and significant element abundance suggest a passive margin tectonic environment for Benue Trough (Ogungbesan and Akaegbobi 2011).

Within the stratigraphic column of the Benue Trough basin, lie the coal beds and coal-bearing strata that are laterally unstable and range from a few centimetres to about $4 \mathrm{~m}$ (Agagu et al. 1985; Sonibare et al. 2008). In the Lower Benue Trough, the coal-bearing Mamu formation is exposed at Okoba, Enugu, Imiegba, Ezimo, Ogboyoga, Orukpa, Udi, on the Enugu-Onitsha Expressway and Agwu-Enugu Escarpment (Ogala 2018). In the Middle Benue Trough, the late Turonian/early Santonian coalbearing Awgu Formation was exposed at Lafia-Obi. Lastly, the coal-bearing Coniacian-Lower Santonian Lamja Formation in the Upper Benue Trough was exposed at Lamja and Chikila villages while Campanian-Maastrichtian Gombe Formation was exposed at GarinMaiganga.

\section{Materials and methods}

\subsection{Sampling locations}

Representative fresh and unweathered channel coal samples were collected from coal beds in a mine from a broad range of locations. The coals are brownish to black in colour, impermeable and occasionally showed lamination. The coals are sometimes fractured and the thickness ranges from about 0.2 to $1.5 \mathrm{~m}$. At each sampling location, the weathered surfaces of the coal beds were removed before the lithological description and collection of channel samples. The channel samples were placed in zip-lock plastic bags and labelled adequately with a felt-tipped marker pen. The samples were taken to the laboratory within a few days after collection to avoid contamination.

\subsection{Sample preparation}

The coal samples were prepared according to the procedures described in the ASTM D-2013 standard (ASTM International 2012b). The coal samples were ground using a hammer mill crusher to reduce the particle size below $2.36 \mathrm{~mm}$ (mesh size-8), before splitting with a sample riffler. Next, the split was further pulverised and sieved into particle size $<850$ microns ( -20 mesh) using a plate grind mill for petrographic analysis. The remainder of the split was further pulverised (using a pulverizer) and sieved (mesh size-60) into $\leq 250$-micron sized particles for geochemical analysis.

\subsection{Proximate, ultimate and calorific analyses}

Proximate analysis (moisture, volatile matter, ash yield, and fixed carbon) was determined by thermogravimetric analysis (TGA Model, LECO thermogravimetric analyser, USA). The analyses were performed at the Center for Applied Energy Research, University of Kentucky (CAER, USA) based on procedures outlined in ASTM Standard D7582-12 (ASTM International 2012c). The total carbon and sulfur analyses were performed at the CAER in accordance with the ASTM D4239-12 standard, using a LECO carbon/sulfur analyser (ASTM International 2012b). The ultimate analysis $(\mathrm{C}, \mathrm{H}, \mathrm{N}, \mathrm{S}$, and $\mathrm{O})$ was determined based on ASTM standard D3176-15 test procedures using a LECO CHN analyser (ASTM International 2015). Triplicate analyses were run on the coal samples. The equations for calculating the total mineral matter (MM) (Speight 2012), HHV (Kieseler et al. 2013), and LHV (Basu 2010) are presented in Eqs. (1)-(3).

$M M=1.08 \mathrm{~A}+0.55 \mathrm{~S}$

$H H V=0.4108 \cdot F C+0.1934 \cdot V M-0.0211 \cdot A s h$

$L H V=H H V-h g(9 H / 100+M / 100)$

where, the $L H V$ denotes the lower heating value $(\mathrm{MJ} / \mathrm{kg})$; $H H V$ denotes higher heating value $(\mathrm{MJ} / \mathrm{kg}) ; h g$ denotes specific heating value of water $(2.26 \mathrm{MJ} / \mathrm{kg}) ; N$ is Nitrogen content; $H$ is hydrogen content; $M$ is moisture content; $F C$ is fixed carbon; $V M$ is volatile matter; $T S$ is total sulphur; $M M$ is total mineral matter; $A$ is ash yield.

\subsection{Organic petrography}

The petrographic composition was determined on the epoxy-bound particulate pellets, prepared to a final 0.05 - 
Table 1 Proximate and ultimate analyses of Cretaceous coals from Benue Trough Basin $(n=3)$

\begin{tabular}{|c|c|c|c|c|c|c|c|c|}
\hline \multirow[t]{2}{*}{ Parameter } & \multicolumn{2}{|l|}{ LBT } & \multicolumn{2}{|l|}{ MBT } & \multicolumn{4}{|l|}{ UBT } \\
\hline & Enugu & Imiegba & Okaba & Lafia-Obi & Chikila & Lamja1 & Lamja2 & Garin-Maiganga \\
\hline \multicolumn{9}{|l|}{ Proximate analysis } \\
\hline Moisture (\%) & 3.17 & 3.77 & 8.63 & 11.59 & 3.07 & 2.98 & 12.91 & 11.35 \\
\hline Volatile matter. dry (\%) & 22.45 & 25.04 & 43.81 & 52.08 & 36.39 & 36.23 & 36.79 & 44.15 \\
\hline Volatile matter. daf (\%) & 52.65 & 63.44 & 52.36 & 56.70 & 39.60 & 39.53 & 48.95 & 46.30 \\
\hline Fixed carbon. dry $(\%)$ & 20.19 & 15.98 & 47.77 & 39.77 & 55.50 & 55.41 & 49.50 & 51.20 \\
\hline Fixed carbon. daf $(\%)$ & 47.35 & 36.56 & 47.64 & 43.30 & 60.40 & 60.47 & 51.05 & 53.70 \\
\hline Ash yield. dry (\%) & 57.36 & 58.97 & 8.42 & 8.16 & 8.11 & 8.36 & 13.71 & 4.65 \\
\hline Total sulfur. dry (\%) & 0.21 & 0.71 & 0.81 & 1.97 & 0.69 & 0.69 & 0.56 & 0.42 \\
\hline \multicolumn{9}{|c|}{ Ultimate analysis (*dry basis) } \\
\hline Hydrogen (\%) & 3.15 & 3.45 & 5.88 & 6.98 & 5.65 & 5.72 & 5.73 & 5.09 \\
\hline Carbon $(\%)$ & 33.23 & 27.40 & 68.65 & 69.90 & 76.39 & 76.48 & 66.04 & 63.07 \\
\hline Nitrogen (\%) & 0.44 & 0.28 & 1.39 & 1.03 & 1.55 & 1.53 & 1.30 & 0.77 \\
\hline Oxygen (\%) & 8.88 & 13.10 & 24.30 & 25.08 & 10.78 & 10.30 & 27.49 & 26.58 \\
\hline $\mathrm{O} / \mathrm{C}$ & 0.27 & 0.48 & 0.35 & 0.36 & 0.14 & 0.13 & 0.42 & 0.42 \\
\hline $\mathrm{H} / \mathrm{C}$ & 0.09 & 0.13 & 0.09 & 0.10 & 0.07 & 0.07 & 0.09 & 0.08 \\
\hline $\mathrm{VM} / \mathrm{FC}$ & 1.11 & 1.57 & 0.92 & 1.31 & 0.66 & 0.65 & 0.74 & 0.86 \\
\hline MM & 62.06 & 64.08 & 9.54 & 9.89 & 9.14 & 9.41 & 15.12 & 5.25 \\
\hline HHV & 11.43 & 10.16 & 27.92 & 26.24 & 29.67 & 29.59 & 27.16 & 29.47 \\
\hline LHV & 10.71 & 9.38 & 26.53 & 24.56 & 28.45 & 28.36 & 25.70 & 28.18 \\
\hline
\end{tabular}

LBT Lower Benue Trough, MBT Middle Benue Trough, UBT Upper Benue Trough

*dry basis $=$ ultimate analysis were done dry basis

$\mu \mathrm{m}$ alumina polish, using a $50 \times$ reflected-light and oilimmersion objective. Maceral descriptions are based on bituminous nomenclature. Vitrinite reflectance was determined using a photometer system with the incident light polarized at $45^{\circ}$ and the light passing across a 546-nm grating.

\subsection{Fourier transform infrared-attenuated total reflectance spectroscopic analysis (FTIR-ATR)}

The functional group chemistry of the selected Nigerian coals was examined by FTIR-ATR spectroscopy (Shimadzu Prestige-21, Japan). The powdered coal samples from the Lower Benue Trough (LBT), Middle Benue Trough (MBT), and Upper Benue Trough (UBT) were sieved to obtain particles below $250 \mu \mathrm{m}$ using an analytical laboratory sieve (Retsch ${ }^{\mathrm{TM}}$, Germany). Next, precisely $5 \mathrm{mg}$ of the selected coal sample was placed on $\mathrm{ZnSe}$ prism plate and scanned to acquire spectra from 4000 to $600 \mathrm{~cm}^{-1}$ based on Happ-Genzel Apodization. Each coal sample was scanned 20 times at a resolution of $8 \mathrm{~cm}^{-1}$ for a duration of $5 \mathrm{~s}$. After each scan, an ATR correction was applied to obtain the FTIR-ATR spectra. Lastly, the raw data was plotted to obtain the FTIR-ATR spectra by Microsoft Excel.

\subsection{Thermogravimetric analysis (TGA)}

The thermal decomposition and non-isothermal degradation of the selected coal samples from the Lower Benue Trough (LBT), Middle Benue Trough (MBT), and Upper Benue Trough (UBT) in Nigeria were conducted by thermogravimetric analysis (TGA). About 23-25 mg of sample was placed in an alumina receptacle before heating from room temperature (RT) to $900{ }^{\circ} \mathrm{C}$ at a heating rate of $30^{\circ} \mathrm{C} /$ min using a Shimadzu TG-50 thermogravimetric analyser (Japan). The TG system was purged with ultra-pure nitrogen $\left(\mathrm{N}_{2}\right)$ gas at a flow rate of $20 \mathrm{~mL} / \mathrm{min}$ to maintain inert conditions and to flush the coal gases evolved during analysis. Upon completion, the TG analyser was cooled to RT, and the raw TGA data files were analysed on a Shimadzu TA-60WS thermal analysis workstation. Based on the recovered ASCII files, the mass loss TG and derivative TG (DTG) data were plotted against temperature to determine the non-isothermal thermal decomposition behaviour and temperature profile characteristics (TPC) of the coals under inert conditions (pyrolysis). The TPCs determined were ignition temperature $\left(T_{\text {onset }}\right)$, midpoint temperature $\left(T_{\mathrm{mid}}\right)$, maximum peak decomposition temperature $\left(T_{\max }\right)$, burnout or offset temperature $\left(T_{\text {off }}\right)$, mass loss and residual mass $\left(R_{\mathrm{M}}, \%\right)$. 


\section{Results and discussion}

\subsection{Proximate, ultimate, and calorific analyses}

The results of the ultimate and proximate analyses of the coal samples are given in Table 1. The average moisture content of coals from Lower Benue Trough (LBT) varies between $3.17 \%$ and $8.63 \%$ and for the coals from Upper Benue Trough (UBT) it ranges from $2.98 \%$ to $12.97 \%$. The Middle Benue Trough (UBT) coal has an average moisture content of $11.59 \%$. The ash yield of LBT coal samples varies between $7.67 \%$ and $56.75 \%$, while for the UBT coal samples it ranges from $4.14 \%$ to $11.94 \%$ (or $7.21 \%$ on average). The ash yields of Enugu and Imiegba coal samples are remarkably high. Furthermore, the moisture and ash yield of the studied coals is higher than Polish coals (0.58 wt $\%, 4.79 \mathrm{wt} \%)$ and American coals (1.07 wt\%, $5.77 \mathrm{wt} \%$ ) (Nasirudeen and Jauro 2011). In contrast, the ash yield of Garin Maiganga coal is significantly lower than most Polish or American coals (Nasirudeen and Jauro 2011). The moisture contents of analyzed coals are considerably higher than the South African coal, but lower in ash yield than the South African coal (dry basis=94.43 wt $\%$ and wet basis $=93.67 \mathrm{wt} \%$ ) (Akinyemi et al. 2012).

With the exception of the Enugu, Imiegba and Lamja2 coals, the ash contents in the other studied coals are relatively low. The higher ash contents in the Enugu, Imiegba and Lamja 2 coals could increase the amount of slag. Low ash yield, typically below $10 \mathrm{wt} \%$, is an essential requirement for good coking coal (Bustin et al. 1985; IEAOECD 2002). The volatile matter (VM) contents of the LBT coal samples varies between $22.45 \%$ and $43.81 \%$ (on dry basis), and $52.08 \%$ for the MBT coal sample. The VM of the UBT coal samples ranges from $36.23 \%$ to $44.15 \%$. The highest VM was observed in the Lafia-Obi coal, followed by Garin-Maiganga coal, and lowest VM of the Enugu coal. The VM of the analyzed coal samples (Except for the Enugu and Imiegba coals) is considerably higher than other Nigerian coals, such as Onyeama (35 wt\%), Ogwashi (27.8 wt\%), Ezimo (32 wt\%), Inyi (30 wt\%), and Ogboyoga (30.4 wt\%) (Ogala et al. 2012; Sambo 2009; Sonibare et al. 2010). Moreover, the VM of the analyzed coal samples except that of Enugu and Imiegba coals is significantly higher than South African coal (dry basis= $5.6 \mathrm{wt} \%$ and wet basis $=6.3 \mathrm{wt} \%)$ (Akinyemi et al. 2012) and Polish coals (32.61 wt\%) (Nasirudeen and Jauro 2011). Conversely, the VM of the studied coals is significantly lower than Hemrin coal seam (60.58 wt\%) (Kettanah and Eble 2017).

The contents of $\mathrm{C}, \mathrm{H}, \mathrm{N}$ are consistent with some selected Nigerian coals (Nyakuma et al. 2017; Vassilev et al. 2015). The highest carbon content was observed in the Lamjal sample, followed by the Chikila coal sample. However, the lowest carbon content coal was obtained from Imiegba. The highest nitrogen content was recorded in the Chikila sample, whereas the lowest was in the Imiegba sample. Hydrogen content is highest in the Lafia-Obi coal, lowest in the Enugu coal. The total sulphur content is highest in the Lafia-Obi coal and lowest in the Enugu coal. The oxygen and hydrogen contents are relatively high compared to nitrogen and total sulphur contents. This observed pattern is in agreement with available data in the literature (Ayinla et al. 2017).

The Okaba, Lafia-Obi, Chikila, Lamja1, Lamja2, and Garin-Maiganga coals with VM greater than $31 \mathrm{wt} \%$ have correspondingly high contents of $\mathrm{C}$ and $\mathrm{H}$ with low mineral matter contents (Table 1). This trend is consistent with high HHV and LHV values for such coal samples. On the other hand, Enugu and Imiegba coals with VM less than $31 \mathrm{wt} \%$ show correspondingly low $\mathrm{C}$ and $\mathrm{H}$ contents. This trend is consistent with high mineral matter content and low HHV and LHV contents of Enugu and Imiegba coals.

Coal rank classification was determined by proximate analysis according to ASTM standard D388 (ASTM International 2012a). Coals with volatile matter (VM) contents higher than $31 \mathrm{wt} \%$ are typically classified according to calorific or higher heating value (HHV) (Speight 2012). Based on this, the Lamja1, Lamja2, and Chikila coals could be classified as high volatile B (HVB) bituminous coal and the Garin-Maiganga, Lafia-Obi, and Okaba coals as sub-bituminous coals. However, an earlier study by Jauro et al. (2008a, b) has classified the Lafia Obi coal as high volatile A bituminous coal. Consequently, the Lamja1 and Chikila coals can be possibly exploited for various energy applications. Nonetheless, the Garin-Maiganga, Lamja2, Lafia-Obi, and Okaba coals are suitable for cement production and electric power generation.

\subsection{Organic petrography}

The vitrinite reflectance of Lafia-Obi coal $\left(\approx 0.39 \% R_{\max }\right)$ and Garin-Maiganga coal $\left(\approx 0.39 \% R_{\max }\right)$ classifies the samples in the subbituminous rank. The vitrinite reflectance obtained from Lamja1 $\left(\approx 0.73 \% R_{\text {max }}\right)$, Lamja2 $(\approx$ $\left.0.72 \% R_{\max }\right)$, and Chikila $\left(\approx 0.71 \% R_{\max }\right)$ coals fall within the high volatile B bituminous rank (Table 2). The vitrinite reflectance of Imiegba $\left(\approx 0.45 \% R_{\text {max }}\right)$ and Okaba $(\approx 0.49 \%$ $R_{\text {max }}$ ) coals classified the samples in the subbituminous rank. The vitrinite reflectance of Enugu coal $(\approx 0.55 \%$ $\left.R_{\max }\right)$, falls on the boundary between subbituminous and high volatile $\mathrm{C}$ bituminous.

The macerals in Cretaceous coals from the Benue Trough Basin (Figs. 10, 11, 12, 13, 14) are mainly vitrinite and inertinite. The vitrinite content is higher than inertinite, despite the small quantities of liptinite and mineral matter 
Table 2 Maceral composition (mineral matter free basis, mmf) and mean reflectance of Cretaceous coals from the Benue Trough

\begin{tabular}{|c|c|c|c|c|c|c|c|c|}
\hline \multirow[t]{2}{*}{ Macerals (mmf) } & \multicolumn{2}{|l|}{ LBT } & \multicolumn{2}{|l|}{ MBT } & \multicolumn{4}{|l|}{ UBT } \\
\hline & Enugu & Imiegba & Okaba & Lafia-Obi & Chikila & Garin-Maiganga & Lamja1 & Lamja2 \\
\hline Telinite & 18.06 & 31.96 & 8.27 & 9.20 & 10.40 & 15.81 & 8.77 & 23.74 \\
\hline Collotelinite & 8.80 & 10.65 & 19.55 & 22.24 & 64.83 & 8.09 & 71.72 & 47.49 \\
\hline Total telovitrinite & 26.86 & 42.62 & 27.82 & 31.45 & 75.23 & 23.90 & 80.48 & 71.23 \\
\hline Vitrodetrinite & 21.30 & 9.77 & 25.19 & 26.08 & 11.44 & 16.91 & 6.77 & 10.06 \\
\hline Collodetrinite & 0.00 & 0.00 & 0.38 & 0.00 & 0.00 & 0.00 & 0.00 & 0.00 \\
\hline Total detrovitrinite & 21.30 & 9.77 & 25.56 & 26.08 & 11.44 & 16.91 & 6.77 & 10.06 \\
\hline Corpogelinite & 5.09 & 4.44 & 3.76 & 3.84 & 3.12 & 2.21 & 0.40 & 3.22 \\
\hline Gelinite & 0.00 & 0.00 & 1.50 & 3.07 & 0.35 & 0.74 & 0.00 & 0.00 \\
\hline Total gelovitrinite & 5.09 & 4.44 & 5.26 & 6.90 & 3.47 & 2.94 & 0.40 & 3.22 \\
\hline Total vitrinite & 53.26 & 56.83 & 58.65 & 64.43 & 90.13 & 43.75 & 87.65 & 84.51 \\
\hline Fusinite & 7.87 & 2.66 & 23.68 & 12.66 & 4.51 & 37.50 & 5.98 & 10.06 \\
\hline Semifusinite & 4.17 & 2.66 & 9.02 & 2.30 & 0.69 & 15.07 & 0.40 & 0.40 \\
\hline Micrinite & 0.00 & 0.00 & 0.00 & 0.38 & 0.00 & 1.10 & 0.00 & 0.00 \\
\hline Macrinite & 0.46 & 0.00 & 0.00 & 0.38 & 0.69 & 0.00 & 0.80 & 0.00 \\
\hline Funginite & 0.00 & 0.00 & 0.38 & 0.38 & 0.35 & 0.00 & 0.40 & 2.01 \\
\hline Inertodetrinite & 0.00 & 0.00 & 0.38 & 1.15 & 0.00 & 0.00 & 0.00 & 0.00 \\
\hline Total inertinite & 12.50 & 5.33 & 33.46 & 17.26 & 6.24 & 53.68 & 7.57 & 12.48 \\
\hline Sporinite & 6.48 & 0.00 & 3.01 & 4.99 & 0.69 & 1.10 & 2.39 & 0.80 \\
\hline Cutinite & 0.93 & 0.00 & 1.50 & 0.00 & 1.73 & 0.74 & 1.59 & 1.21 \\
\hline Resinite & 6.48 & 0.00 & 2.63 & 10.35 & 0.00 & 0.74 & 0.00 & 0.40 \\
\hline Suberinite & 0.00 & 0.00 & 0.38 & 0.00 & 0.00 & 0.00 & 0.00 & 0.00 \\
\hline Total liptinite & 13.89 & 0.00 & 7.52 & 15.34 & 2.43 & 2.57 & 3.98 & 2.41 \\
\hline Silicate & 37.24 & 75.00 & 0.75 & 3.35 & 2.40 & 0.00 & 1.58 & 0.80 \\
\hline Sulfide & 0.34 & 0.35 & 0.00 & 1.86 & 0.00 & 0.00 & 0.00 & 0.40 \\
\hline Other & 3.10 & 0.35 & 0.00 & 0.74 & 0.00 & 0.00 & 0.00 & 0.00 \\
\hline Total mineral & 40.69 & 75.69 & 0.75 & 5.95 & 2.40 & 0.00 & 1.58 & 1.20 \\
\hline$R_{\text {max }}^{\circ}(\%)$ & 0.55 & 0.45 & 0.49 & 0.39 & 0.71 & 0.39 & 0.73 & 0.72 \\
\hline Stdev. & 0.05 & 0.05 & 0.03 & 0.02 & 0.04 & 0.03 & 0.03 & 0.03 \\
\hline$R_{\text {random }}^{\circ}(\%)$ & 0.52 & 0.42 & 0.45 & 0.35 & 0.66 & 0.35 & 0.67 & 0.69 \\
\hline Stdev. & 0.04 & 0.04 & 0.04 & 0.03 & 0.05 & 0.03 & 0.05 & 0.04 \\
\hline
\end{tabular}

(Table 2). The total vitrinite content shows the highest abundance in the UBT coals followed by the LBT coals and lowest content for the MBT coal. The vitrinite group (Fig. 4) signifies woody plant material (e.g., stems, trunks, roots, and branches), resulting from lignin and cellulose of plant tissues. The woody and herbaceous cell tissue (lignin and cellulose) form macerals of the vitrinite group. The vitrinite macerals were formed under anaerobic (high hydrogen content) and mostly reducing conditions. The vitrinite group are dominated by telinite, collotelinite (Fig. 4), and detrovitrinite, which are smaller fragments, showing a higher degree of degradation and generally forming the groundmass for other macerals. The vitrinite in the Lamja2 and Imiegba coals are dominated by telinite and collotelinite (telovitrinite), which are intact compressed fragments of woody material of varying degree of compaction. Vitrinite is fairly abundant in all the investigated coal samples and shows the highest content in the Chikila coal, followed by the Lamja1 coal, and least in the Garin-Maiganga coal. The mineral contents in the Enugu and Imiegba (LBT) coals are high compared to other studied coal samples. The argillaceous minerals matter and other mineral groups mostly observed are; silicates, clay minerals, pyrites and jarosite formed by chemical precipitation (Diessel 1992; Singh et al. 2013, 2015; Gangadharan et al. Gangadharan et al. 2019).

Inertinites are mainly oxidation products of other macerals and are consequently richer in carbon than liptinites or vitrinites. The highest concentration of inertinite is recorded in coals from the Upper Benue Trough (UBT) 

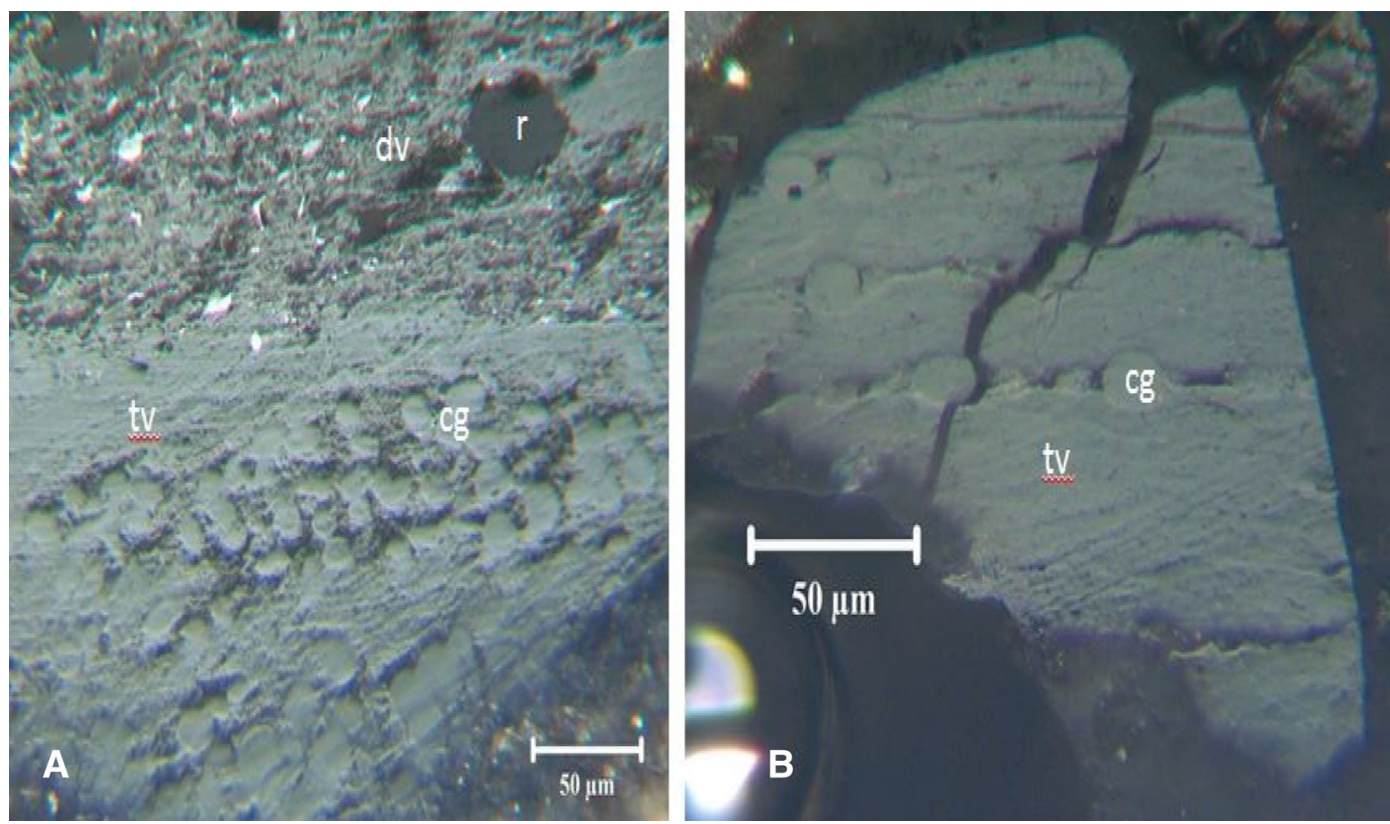

Fig. 4 Vitrinite (a) Corpogelinite (cg) with telovitrinite (tv) and a mix of resinite (r), detrovitrinite, and other detrital macerals (b) Corpogelinite (cg) with telovitrinite (tv)
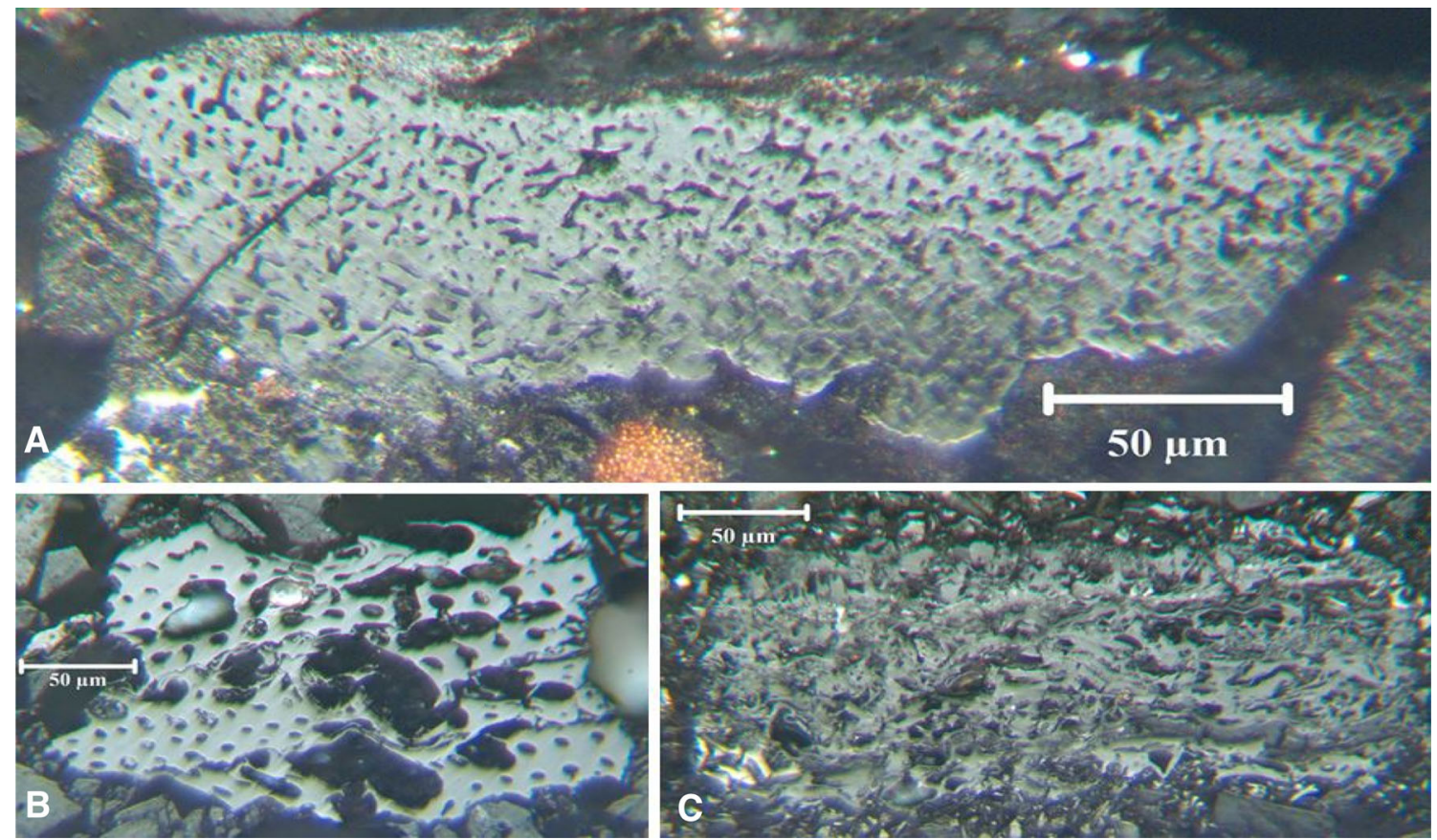

Fig. 5 Fusinite and semifusinite a degraded fusinite showing "shotgun" pattern suggestive of fungal attack b degrade fusinite showing swollen cell walls $\mathbf{c}$ broken semifusinite walls with some brighter fusinite (lower left)

followed by the coals from Lower Benue Trough (LBT), and lowest inertinite contents are obtained in the coal from Middle Benue Trough (MBT). The highest inertinite content is recorded in the Garin-Maiganga coal (53.68\%), followed by the Lafia-Obi coal, and minor quantities occur in other coal samples. The inertinite macerals are dominated by fusinite and semifusinite (Fig. 5). Fusinite and semifusinite are, in part, derived from ancient fires in the coal-forming peat (Scott 1998). Macrinite is obviously present in the Enugu, Lafia-Obi, Chikila, and Lamja1 coals. Macrinite proved to be a crucial diagnostic maceral in a previous study of Nigerian Cretaceous coals (Hower et al. 1998). Macrinite originated from the biological decomposition and decay of plant material. Micrinite characterised 

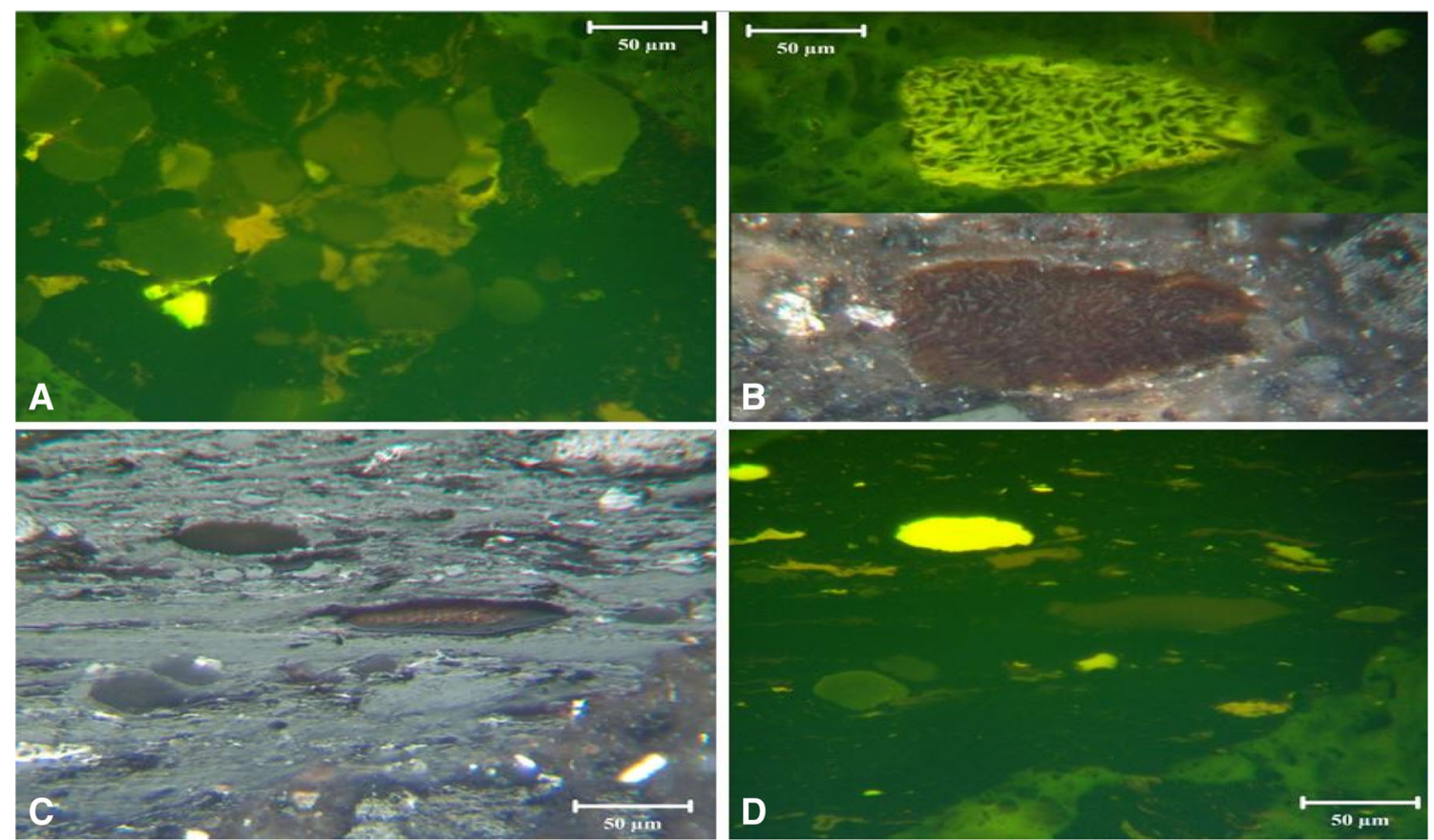

Fig. 6 Resinite a blue-light image of resinite $\mathbf{b}$ blue-light/white-light images of resinite $\mathbf{c}$, d blue-light and white-light images of resinite
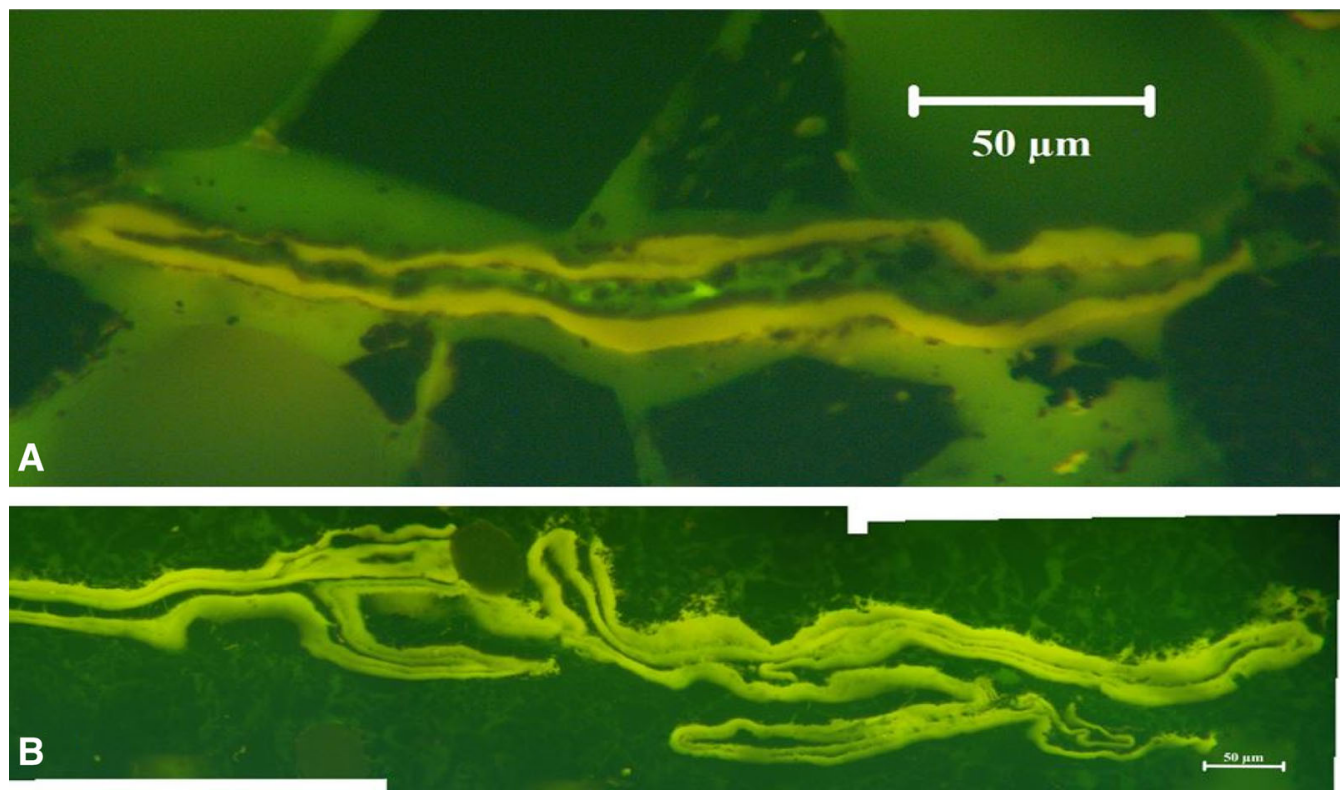

Fig. 7 Sporinite a blue-light images of sporinite $\mathbf{b}$ sporinite

the Lafia-Obi and Garin Maiganga coals, which are formed from thermal maturation of peat. The relatively high abundance of inertinite maceral group content suggests that the coal deposition occurred at shallow depths under aerobic condition with frequent exposure of plant debris (Chaudhuri et al. 2001).

The highest abundance of liptinites is recorded in the LBT coals, followed by MBT coal, and the least concentration is observed in the UBT coals. Liptinite shows the highest content in the Lafia-Obi coal, followed by the Enugu coal, with the least abundance being recorded in the Lamja2 coal samples. Liptinites are derived from spores, pollens, cuticles, and resins in the original plant material. The liptinite group of macerals is enriched in hydrogen compared to the vitrinite and inertinite groups. Liptinite macerals are also highly reactive due to the higher volatile content, which contribute more to the by-products. Liptinites (Figs. 6, 7, 8) occur in variable amounts, rising 
above $10 \%$ in the Lafia-Obi and Enugu coals. Resinite largely accounts for the liptinite in the Lafia-Obi coal, is co-equal with sporinite in the Enugu coal and nearly equal to sporinite in the Okaba coal (total liptinite of $7.5 \%$, on the mineral-free basis). The liptinite distribution pattern could be attributed to changes in vegetation and freshwater conditions in the depositional environment (Ao et al. 2012). The relatively high vitrinite and low inertinite in the coal seam from Benue Trough indicates that anaerobic condition of deposition i.e. high water content or anoxic condition prevailed during early peat stage development of the peat swamp. Maceral of the studied coal samples trends from fluvial to lacustrine condition during peat swamp development, which indicates that the coals were deposited under the fluvio-lacustrine environment.

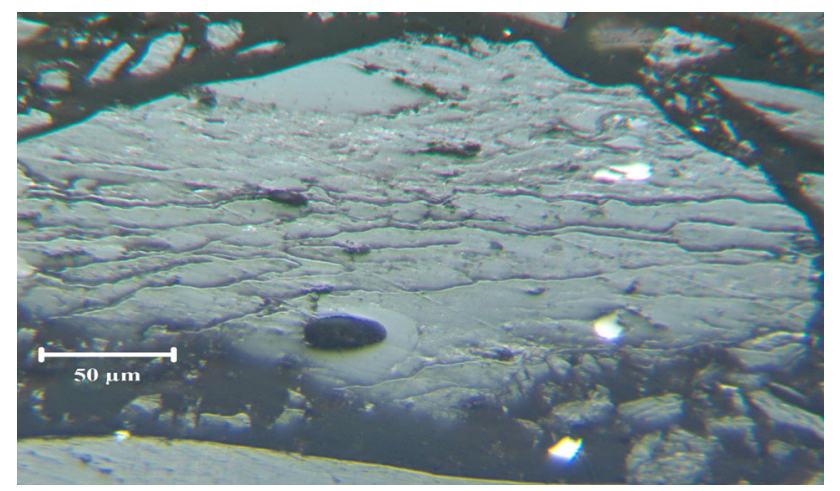

Fig. 8 Cutinite, thin cell wall, fine and bent as a wire, dispersed in degradinite

\subsection{Depositional environment}

The petrographic composition of studied coal seams can be used to reconstruct the paleoenvironment of the coal formation in the Benue Trough Basin. Some authors (Grady et al. 1993; Obaje et al. 1994; Shearer and Clarkson 1998) have demonstrated the influence of the paleodepositional environment on the quantifiable dissemination of macerals in the coal seams, predominantly in relation to time. The abundance of vitrinite (telinite and Collotelinite) and inertinite (fusinite and semifusinite) in the studied coal samples particularly suggests deposition in wet forest swamp sub-environments along within lagoons. The observed relative abundance of inertinite maceral in the Okaba and Garin-Maiganga coals could also be attributed to dryness experienced by these sections of the basin (Singh et al. 2013; Rajak et al. 2019). This dryness as indicated by elevated inertinite content is ascribed to regression episode that occurred during the first tectonic phase or local fluctuation in the water level. The relative abundance of mineral matter in Enugu and Imiegha (LBT) coals suggests that the Lower Benue Trough section of the basin was inundated with clastic marsh depositional environment.

\subsection{FTIR-ATR analysis}

FTIR-ATR technique is used in this study to determine the chemical structure and composition of the coal samples. The FTIR spectra for the coal samples from the Upper Benue Trough (UBT), i.e., Chikila (CHK), Garin Maiganga

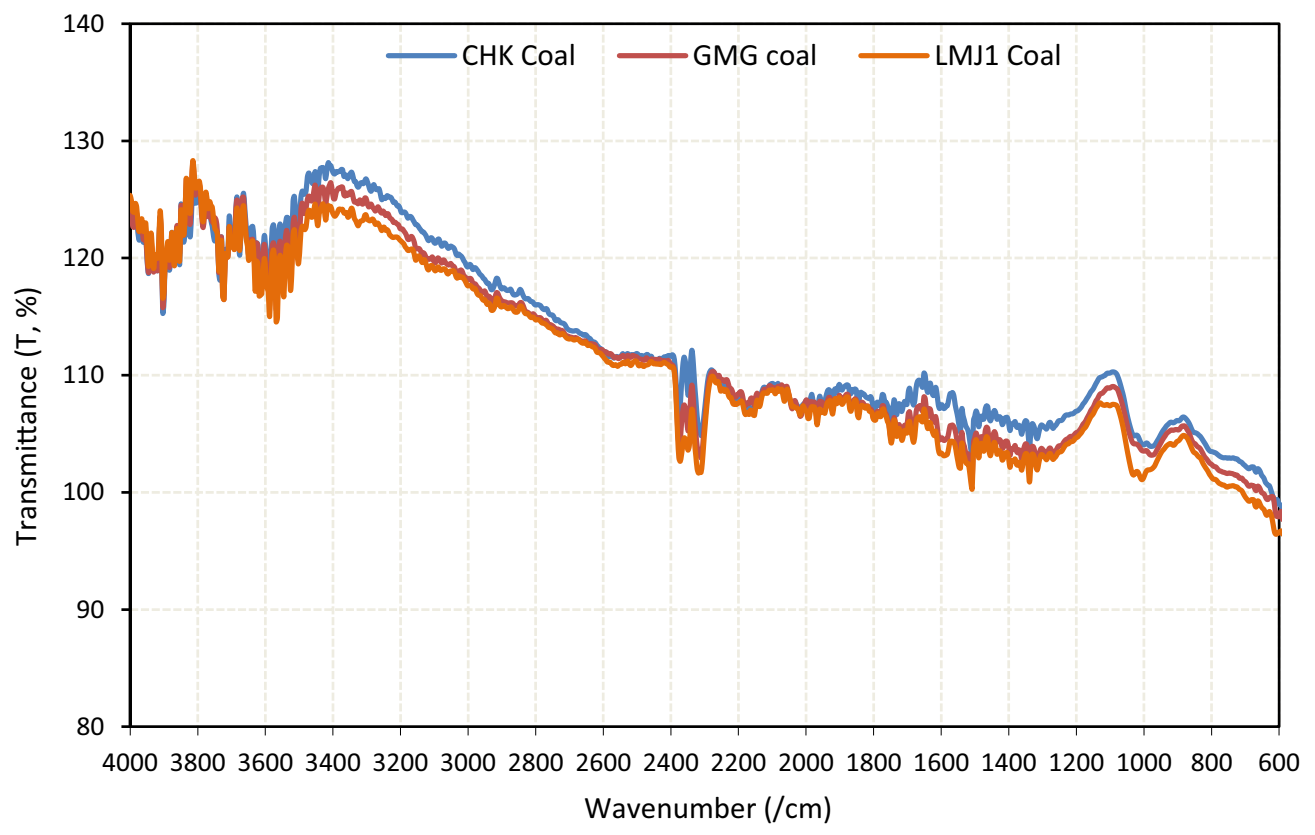

Fig. 9 FTIR of Upper Benue Trough (UBT) coals 


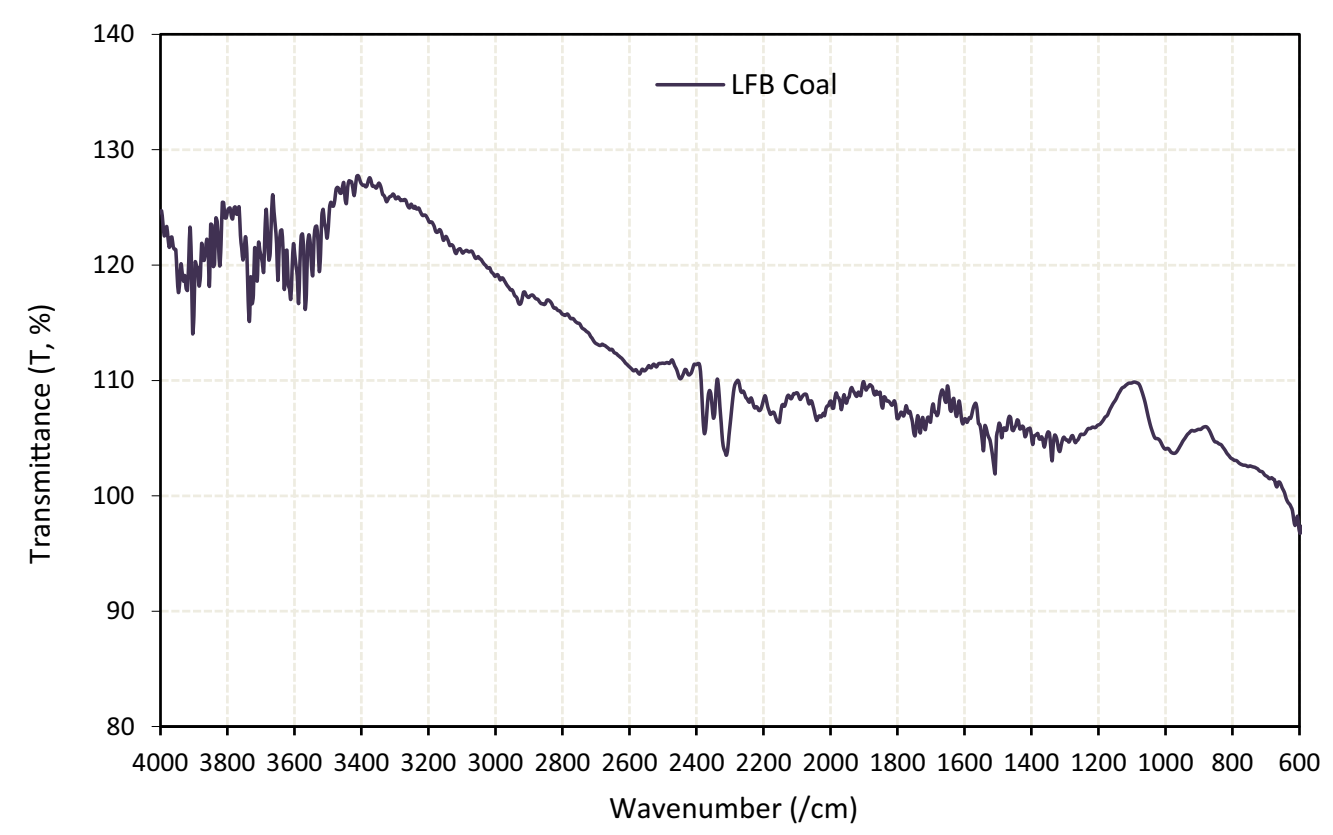

Fig. 10 FTIR of Middle Benue Trough (MBT) coal

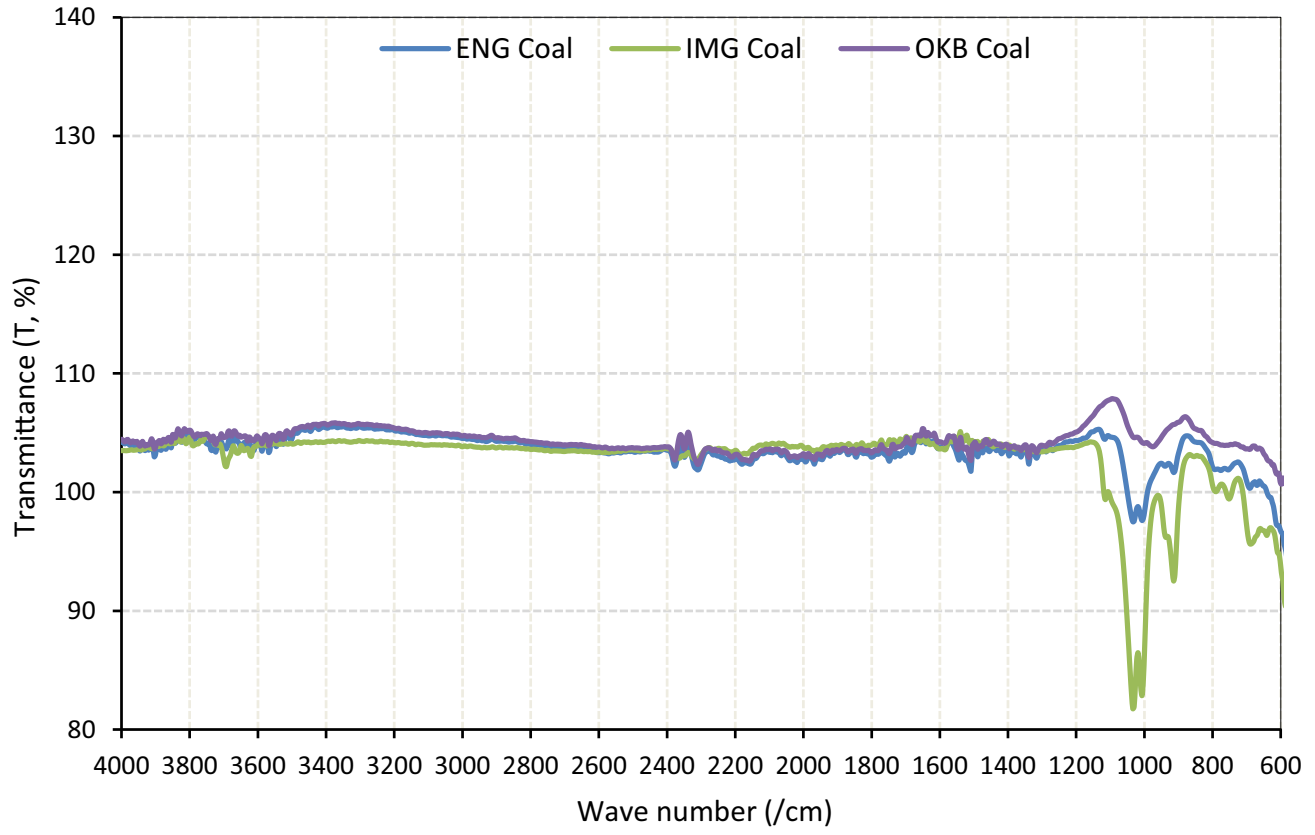

Fig. 11 FTIR of Lower Benue Trough (LBT) coal

(GMG), and Lamja1 (LMJ) are presented in Fig. 9, the Lafia-Obi (LFB) coal from the Middle Benue trough (MBT) in Fig. 10, and the Enugu (ENG), Imiegba (IMG) and Okaba (OKB) from the Lower Benue Trough (LBT) in Fig. 11. Several FT-IR peaks of variable intensities occur that can be ascribed to various organic functional groups.

The medium to sharp peaks observed between 2400 and $2200 \mathrm{~cm}^{-1}$ can be ascribed to the asymmetric stretching vibrations of the isocyanate $(\mathrm{C}=\mathrm{N}=\mathrm{O})$ group. The peaks were more prominent for the UBT coals, i.e., the CHK, GMG, and LMJ1. However, the intensities declined for ENG, IMG, and OKB coals (LBT coals). The medium peak at $1600 \mathrm{~cm}^{-1}$ can be assigned to hydrogen-bonded $\mathrm{C}=\mathrm{O}$ or non-chelated quinoid carbonyl groups (Basaran et al. 2003). Other studies have assigned the peak to the aromatic $\mathrm{C}=\mathrm{C}$ stretching (Georgakopoulos et al. 2003; Balachandran 2014), which is caused by strong absorptions due to the high carbon content in coals (Balachandran 2014). The 

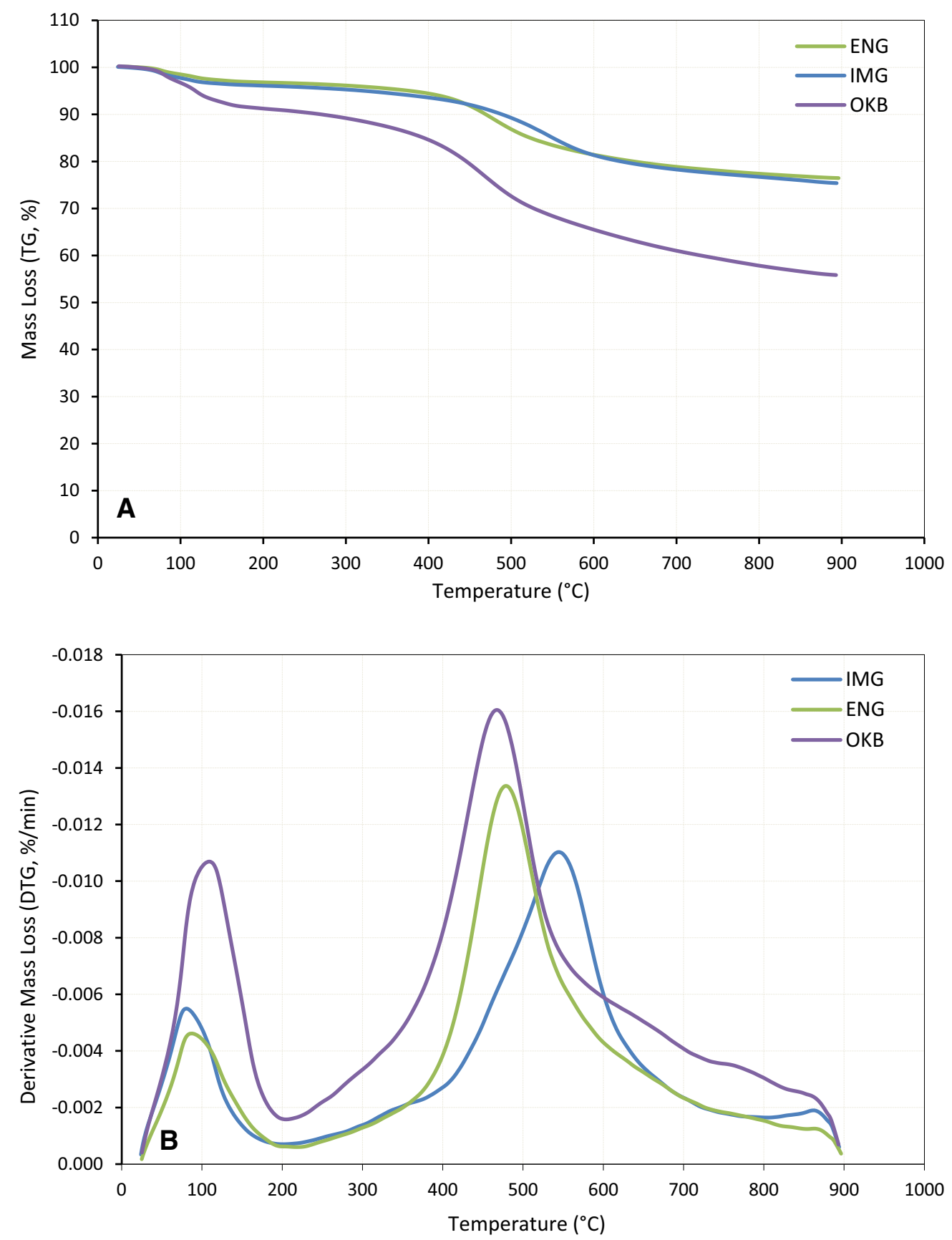

Fig. 12 a Pyrolysis-TG plots of LBT coals. b Pyrolysis-DTG plots for LBT coals

intensity of this peak is an indicator of the coal rank (Speight 2012). The peaks or bands observed at $1500 \mathrm{~cm}^{-1}$, typically present in low-rank coals (Balachandran 2014), can be ascribed to condensed aromatic rings $\mathrm{C}=\mathrm{C}$.

However, the peaks at $1400 \mathrm{~cm}^{-1}$ and $1300 \mathrm{~cm}^{-1}$ are due to aliphatic and cyclic $\mathrm{CH}_{2}$ and $\mathrm{CH}_{3}$ groups. The absorption bands between 800 and $600 \mathrm{~cm}^{-1}$ are due to the hydrogen atoms on the substituted aromatic rings. This could also be due to the out-of-plane vibrations of aromatic $\mathrm{CH}$ groups, which are an indication of the degree of condensation of aromatic clusters in coals (Speight 2012). The sharp peaks observed between 4000 and $3400 \mathrm{~cm}^{-1}$ are due to the rota-vibrational bands of water vapour (Georgakopoulos et al. 2003; Zhang et al. 2015), indicating that inherent water molecules or characteristic residual moisture were included in the coals. 

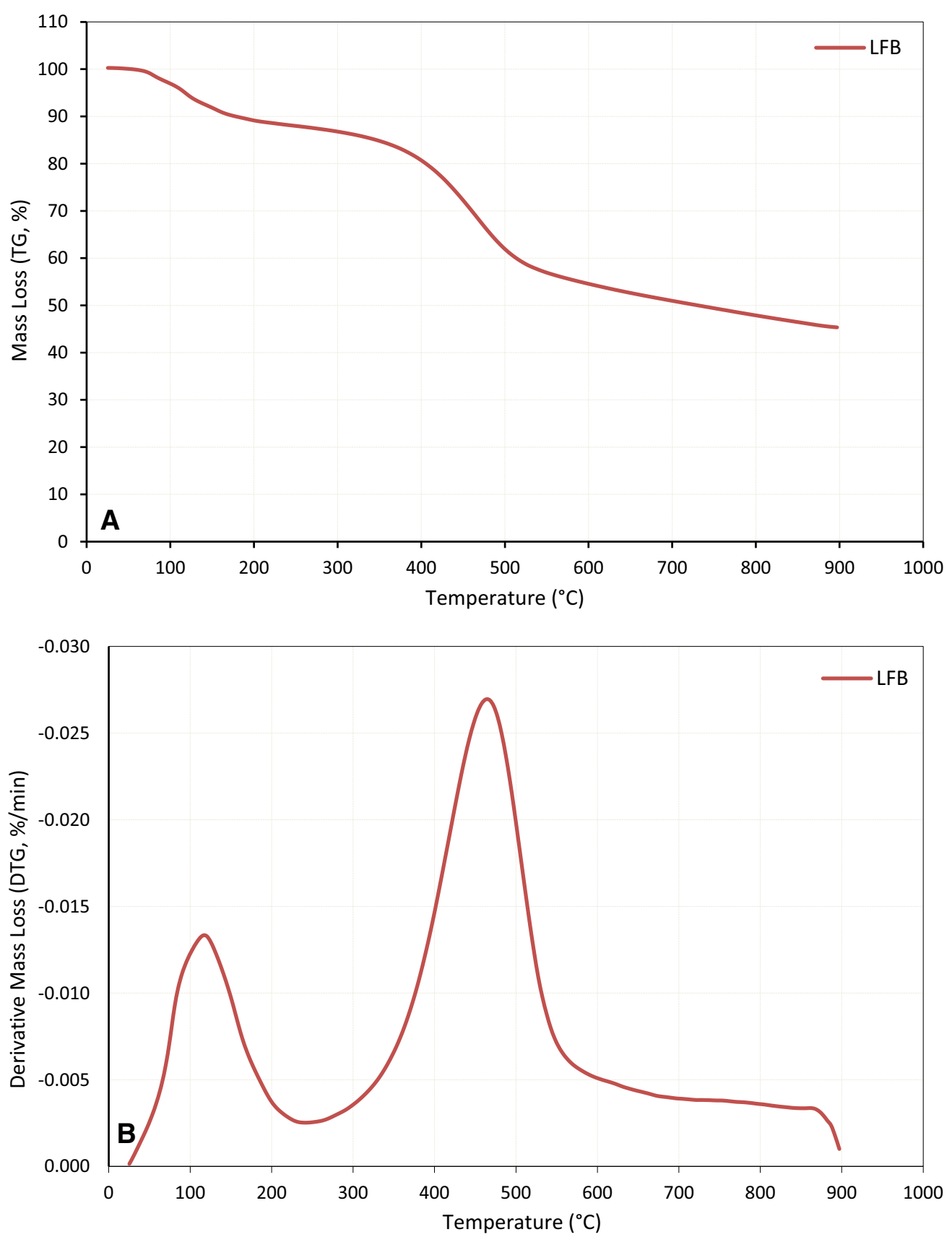

Fig. 13 a Pyrolysis-TG plots for MBT coal. b Pyrolysis-DTG plots for MBT coal

\subsection{TGA pyrolysis}

The TG-DTG plots for the non-isothermal thermal degradation of the selected LBT, MBT and UBT coals in Nigeria are presented in Figs. 12, 13 and 14. Figure 12a presents the TG plots for the LBT coals; Enugu (ENG), Imiegba (IMG), and Okaba (OKB). Figure 13a presents the TG plots for the MBT coal; Lafia-Obi (LFB). Lastly, the TG plots for the thermal decomposition of the UBT coals; Chikila (CHK), Garin Maiganga (GMG), and Lamja1 (LMJ) are presented in Fig. 9a. The TG plots exhibited downward sloping curves, indicating the increase in temperature from RT to $900{ }^{\circ} \mathrm{C}$ resulting in a steady thermal degradation as denoted by the mass loss $\left(M_{\mathrm{L}}, \%\right)$, residual mass $\left(R_{\mathrm{M}}, \%\right)$, and temperature profile characteristics (TPC) as presented in Table 3.

The mass loss for the UBT coals, i.e., CHK, GMG, and LMJ, was from $32.39 \%$ to $49.32 \%$. The highest mass loss $(49.32 \%)$ was observed for the GMG, indicating that it is the most reactive coal sample. The CHK coal is the least reactive with a mass loss of $32.39 \%$. Consequently, the residual mass of the coals were $67.61 \%$ for $\mathrm{CHK}, 50.68 \%$ 

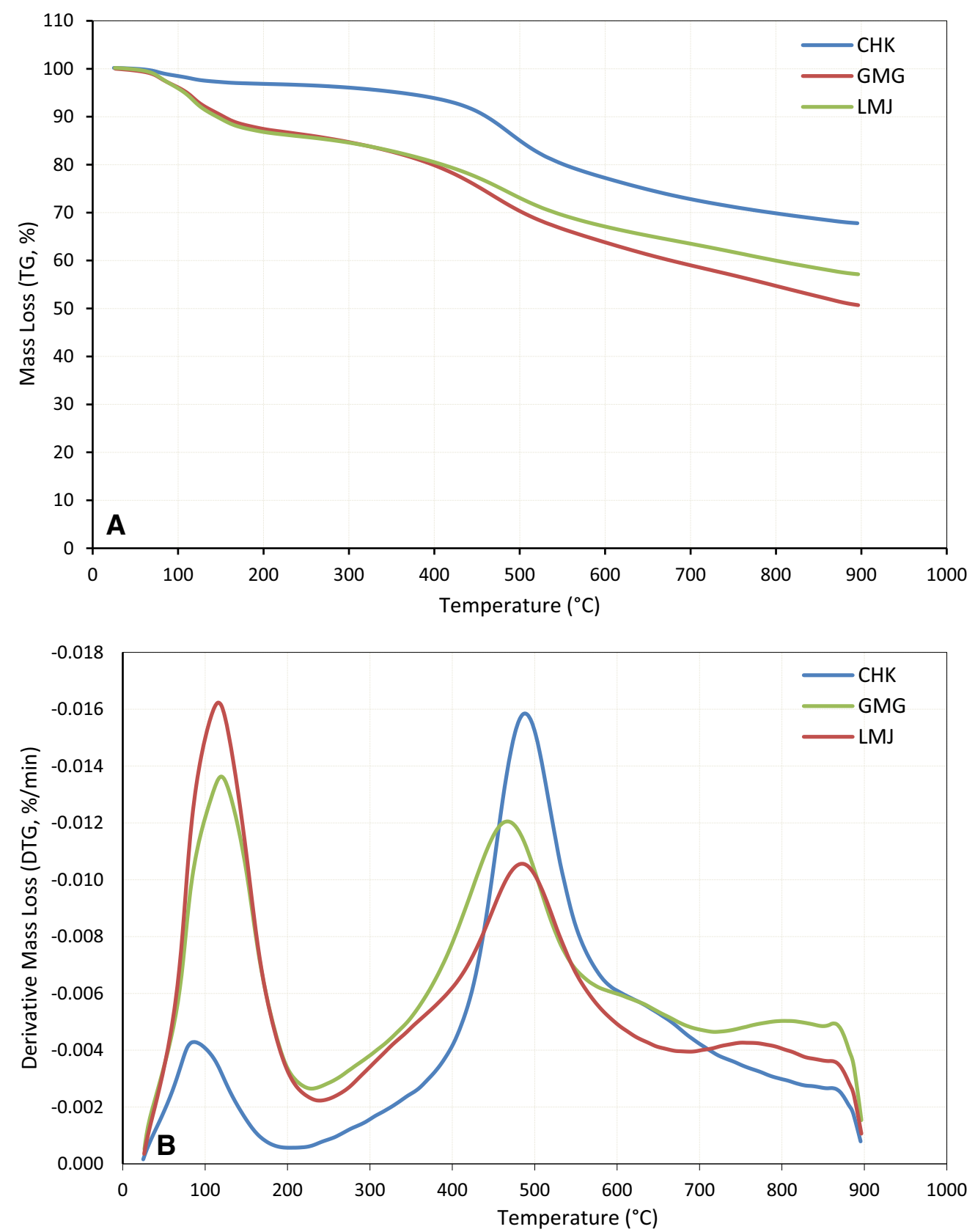

Fig. 14 a Pyrolysis-TG plots for the UBT coals. b Pyrolysis-DTG plots for UBT coals

for $\mathrm{GMG}$, and $56.98 \%$ for $\mathrm{LMJ} 1$. The $\mathrm{M}_{\mathrm{L}}$ and $\mathrm{R}_{\mathrm{M}}$ for $\mathrm{LFB}$ were $54.93 \%$ and $45.07 \%$, respectively. This indicates that LFB is less thermally stable and, hence, more reactive than the UBT coals. The $M_{\mathrm{L}}$ and $R_{\mathrm{M}}$ for the LBT coals, i.e., ENG, IMG, and OKB ranged from $23.72 \%$ to $44.42 \%$, and $55.58 \%$ to $76.28 \%$, respectively.

The highest mass loss $(44.42 \%)$ was observed for the OKB coal, whereas the lowest mass loss (23.72\%) was observed for the ENG coal. The results indicate that the $\mathrm{OKB}$ coal is most reactive, or least thermally stable coal, examined whereas the ENG coal is the least reactive, or most thermally stable. In general, the results demonstrate that, on average, the mass loss and residual mass for the coals examined are $37.31 \%$ and $62.69 \%$, respectively. Lastly, the results indicate that higher temperatures above $900{ }^{\circ} \mathrm{C}$ are required to decompose the coals for efficient energy recovery.

The thermal degradation and chemical reactivity of the coals during the pyrolysis thermal decomposition was also examined through the TPCs. The $T_{\text {onset }}$, for the UBT coals, ranged from $77.86{ }^{\circ} \mathrm{C}(\mathrm{LMJ})$ to $393.67{ }^{\circ} \mathrm{C}(\mathrm{CHK})$, the $T_{\text {mid }}$ from $362.60{ }^{\circ} \mathrm{C}(\mathrm{LMJ})$ to $498.25{ }^{\circ} \mathrm{C}(\mathrm{CHK})$, and the $T_{\text {off }}$ 
Table 3 Thermogravimetric plot data

\begin{tabular}{lllllll}
\hline $\begin{array}{l}\text { Coal } \\
\text { samples }\end{array}$ & $\begin{array}{l}\text { Region } \\
\text { of } \\
\text { origin }\end{array}$ & $\begin{array}{l}\text { Onset } \\
\text { temp } \\
\left(T_{\text {onset }},\right. \\
\left.{ }^{\circ} \mathrm{C}\right)\end{array}$ & $\begin{array}{l}\text { Midpoint } \\
\text { temp. } \\
\left(T_{\text {mid }},{ }^{\circ} \mathrm{C}\right)\end{array}$ & $\begin{array}{l}\text { Offset } \\
\text { temp. } \\
\left(T_{\text {off }},{ }^{\circ}\right. \\
\mathrm{C})\end{array}$ & $\begin{array}{l}\text { Mass } \\
\text { loss } \\
\left(M_{\mathrm{L}},\right.\end{array}$ & $\begin{array}{l}\text { Residual } \\
\text { mass } \\
\left(R_{\mathrm{M}}, \%\right)\end{array}$ \\
\hline CHK & UBT & 393.67 & 498.25 & 612.43 & 32.39 & 67.61 \\
GMG & UBT & 81.38 & 401.95 & 421.50 & 49.32 & 50.68 \\
LMJ $^{1}$ & UBT & 77.86 & 362.60 & 310.70 & 43.03 & 56.98 \\
LFB & MBT & 327.15 & 437.97 & 558.05 & 54.93 & 45.07 \\
ENG & LBT & 381.78 & 479.44 & 589.90 & 23.72 & 76.28 \\
IMG & LBT & 408.88 & 509.27 & 638.39 & 24.72 & 75.28 \\
OKB & LBT & 317.71 & 451.23 & 604.54 & 44.42 & 55.58 \\
\hline
\end{tabular}

Table 4 Derivative Thermogravimetric Data

\begin{tabular}{llcl}
\hline $\begin{array}{l}\text { Coal } \\
\text { samples }\end{array}$ & $\begin{array}{l}\text { Region of } \\
\text { origin }\end{array}$ & $\begin{array}{l}\text { Drying peak } \\
T_{\text {dry }}\left({ }^{\circ} \mathrm{C}\right)\end{array}$ & $\begin{array}{l}\text { Decomposition peak } \\
T_{\max }\left({ }^{\circ} \mathrm{C}\right)\end{array}$ \\
\hline CHK & UBT & 88.32 & 485.94 \\
GMG & UBT & 119.85 & 467.26 \\
LMJ $^{1}$ & UBT & 115.72 & 482.09 \\
LFB & MBT & 116.62 & 462.72 \\
ENG & LBT & 89.13 & 476.87 \\
IMG & LBT & 81.62 & 544.16 \\
OKB & LBT & 109.21 & 468.93 \\
\hline
\end{tabular}

from $310.70{ }^{\circ} \mathrm{C}\left(\mathrm{LMJ}^{1}\right)$ to $612.43{ }^{\circ} \mathrm{C}(\mathrm{CHK})$ (Table 2), confirming that the $\mathrm{CHK}$ is the least reactive UBT coal under the conditions examined in this study. The characteristic temperature profiles for the MBT coal LFB were $T_{\text {onset }},\left(327.15^{\circ} \mathrm{C}\right), T_{\text {mid }}\left(437.97{ }^{\circ} \mathrm{C}\right)$, and $T_{\text {off }}\left(558.05^{\circ} \mathrm{C}\right)$. The values are higher than reported for the UBT coals GMG and $\mathrm{LMJ}^{1}$ but somewhat comparable to the CHK.

The characteristic temperature profiles, e.g., $T_{\text {onset }} T_{\text {mid }}$, and $T_{\text {off }}$ for LBT coals, i.e., ENG, IMG, and OKB, were also examined. The values for $T_{\text {onset }}$, ranged from 317.71 to $408.88{ }^{\circ} \mathrm{C}, T_{\text {mid }}$ from 451.23 to $509.27{ }^{\circ} \mathrm{C}$, and $T_{\text {off }}$ from 589.90 to $638.39{ }^{\circ} \mathrm{C}$. The lowest $T_{\text {onset }}$, was observed for the OKB coal whereas the highest was for the IMG coal. Likewise, for $T_{\text {mid }}$, the lowest value was observed for the OKB coal and the highest was observed for the IMG coal. The lowest $T_{\text {off }}$ was observed for the ENG coal and the highest was for the IMG coal.

The DTG plots for the pyrolytic decomposition of the UBT, MBT, and LBT coals are presented in Figs. 12b, 13b, and $14 \mathrm{~b}$, respectively. The plots are characterised by two sets of endothermic peaks in the regions; RT $-250{ }^{\circ} \mathrm{C}$ and 250-700 ${ }^{\circ} \mathrm{C}$, indicating that the thermal decomposition of the coals occurs in three stages: I-drying, II-devolatilization, and III-coke formation above $700{ }^{\circ} \mathrm{C}$.
Stage I is typically characterised by the loss of moisture and low molecular weight volatile compounds in the coal. However, stage II is due to the loss of high molecular weight constituents of coal, resulting in the production of condensable and non-condensable products. The last stage III denoted by the tailing observed after $700{ }^{\circ} \mathrm{C}$ for the coals may be ascribed to coke formation and other gassolid products. The weight loss during stages I and II are characterised by maximum decomposition peaks denoted as the Drying Peak $\left(T_{\text {dry }}\right)$ and Decomposition Peak $\left(T_{\max }\right)$ as presented in Table 4.

As observed in Table 3, the $T_{\text {dry }}$ and $T_{\max }$ values for the UBT coals ranged from 88.32 to $119.85{ }^{\circ} \mathrm{C}$ and from 467.26 to $485.94{ }^{\circ} \mathrm{C}$, respectively. Based on the results, the highest $T_{\text {dry }}$ peak was observed for the GMG coal, corresponding to its high moisture content compared to the CHK coal, which has the lowest $T_{\text {dry }}$ peak value (Table 1). The highest $T_{\max }$ value was observed for the CHK coal whereas the lowest was for the GMG coal. The $T_{\mathrm{dry}}$ and $T_{\max }$ values for the MBT and LFB coals are $116.62{ }^{\circ} \mathrm{C}$ and $462.72{ }^{\circ} \mathrm{C}$, respectively, within the range observed for the UBT coals. Lastly, the $T_{\text {dry }}$ and $T_{\max }$ for the LBT coals ranged from 81.62 to $109.21{ }^{\circ} \mathrm{C}$ and 468.93 to $544.16{ }^{\circ} \mathrm{C}$.

\section{Conclusions}

This study conducted the physicochemical analysis, maceral analysis, FTIR-ATR analysis, and thermogravimetric analysis of the Cretaceous coal from Benue Trough sedimentary basin, Nigeria. The study revealed findings on the rank classification, deposition environment, thermal decomposition and reactivity. The following conclusions can be made:

(1) Based on vitrinite reflectance, GMG, IMG, and OKB coals are categorised as subbituminous rank, while LMJ1, LMJ2 and CHK coals are identified as high volatile B bituminous. The Enugu (ENG) coal is classified as high volatile $\mathrm{C}$ bituminous.

(2) The vitrinite and fusinite contents show a gradual increase from LBT coals to the UBT coals. Semifusinite and total mineral matter follow a contrary pattern.

(3) Relatively high vitrinite and low inertinite contents indicate the anaerobic condition of deposition and maceral trend show deposition under fluvio lacustrine environment.

(4) Thermal decomposition occurred in three stages, i.e., drying, devolatilization, and coke formation (above $700{ }^{\circ} \mathrm{C}$ ). Therefore, high temperature above $900{ }^{\circ} \mathrm{C}$ is required to decompose the coals for efficient energy recovery. 
(5) The order of reactivity of studied coals is as follows: $\mathrm{LFB}>\mathrm{GMG}>\mathrm{OKB}>\mathrm{LMJ}>\mathrm{CHK}>\mathrm{IMG}>\mathrm{ENG}$.

(6) Based on the volatile matter and higher heating value, the Garin-Maiganga, Lamja2, Lafia-Obi Okaba, Lamja1, and Chikila coals can be possibly exploited for various energy applications. However, the Enugu and Imiegba coals would be best suited for cement and power electricity generation. Nevertheless, extensive tests are required to confirm their intrinsic potentials for application in the abovementioned technologies.

Acknowledgements The authors gratefully acknowledge Mr Faweya at Cartography Laboratory, Department of Geology \& Applied Geophysics, Ekiti State University (Nigeria) for the map. The authors are also grateful to the Centre of Hydrogen Energy, Universiti Teknologi Malaysia for assistance with the FTIR-ATR and TGA. This study was supported through Research Grant from the Tertiary Education Trust Fund (TETFUND), Nigeria.

Open Access This article is licensed under a Creative Commons Attribution 4.0 International License, which permits use, sharing, adaptation, distribution and reproduction in any medium or format, as long as you give appropriate credit to the original author(s) and the source, provide a link to the Creative Commons licence, and indicate if changes were made. The images or other third party material in this article are included in the article's Creative Commons licence, unless indicated otherwise in a credit line to the material. If material is not included in the article's Creative Commons licence and your intended use is not permitted by statutory regulation or exceeds the permitted use, you will need to obtain permission directly from the copyright holder. To view a copy of this licence, visit http://creativecommons. org/licenses/by/4.0/.

\section{References}

Abubakar MB, Obaje NG, Luterbacher HP, Dike EFC, Ashraf AR (2006) A report on the occurrence of Albian-Cenomanian elaterbearing pollen in Nasara-1 well, Upper Benue Trough, Nigeria. J Afr Earth Sci 45(3):347-354

Adedosu T, Adedosu H, Adebiyi F (2007) Geochemical and mineralogical significance of trace metals in Benue Trough coals, Nigeria. J Appl Sci 7:3101-3105

Agagu OK, Fayose EA, Petters SW (1985) Stratigraphy and sedimentation in the Senonian Anambra Basin of eastern Nigeria. J Min Geol 22:25-36

Akinyemi S, Gitari W, Akinlua A, Petrik L (2012) Mineralogy and geochemistry of sub-bituminous coal and its combustion products from Mpumalanga Province, South Africa. In: Analytical chemistry. InTech

Akpabio I, Chagga M, Jauro A (2008) Assessment of some Nigerian coals for metallurgical application. J Miner Mater Charact Eng 7:301

Aliyu AS, Ramli AT, Saleh MA (2013) Nigeria electricity crisis: power generation capacity expansion and environmental ramifications. Energy 61:354-367

Aniefiok E, Igweonu IE, Eguzo CV, Robert BJ (2013) Integrating smart grid model in Nigeria power network. Int J Adv Eng Technol 6:1760
Ao W et al (2012) Coal petrology and genesis of Jurassic coal in the Ordos Basin, China. Geosci Front 3:85-95

ASTM International (2012a) ASTM D388-12 Standard classification of coals by rank. ASTM International, West Conshohocken

ASTM International (2012b) ASTM D2013/D2013M-12 Standard practice for preparing coal samples for analysis. ASTM International, West Conshohocken

ASTM International (2012c) ASTM D7582-12 Standard test methods for proximate analysis of coal and coke by macro thermogravimetric analysis. ASTM International, West Conshohocken

ASTM International (2015) ASTM D3176-15 Standard practice for ultimate analysis of coal and coke. ASTM International, West Conshohocken

Avbovbo AA (1980) Basement geology in the sedimentary basins of Nigeria. Geology 8:323-327

Ayinla HA et al (2017) Source rock characteristics, depositional setting and hydrocarbon generation potential of Cretaceous coals and organic-rich mudstones from Gombe Formation, Gongola sub-basin, Northern Benue Trough, NE Nigeria. Int J Coal Geol 173:212-226

Balachandran M (2014) Role of infrared spectroscopy in coal analysis -an investigation. Am J Anal Chem 5:367

Başaran Y, Denizli A, Sakintuna B et al (2003) Bio-liquefaction/solubilization of low-rank Turkish lignites. Energy Fuel 17:10681074

Basu P (2010) Biomass gasification and pyrolysis: practical design and theory. Academic Press/Elsevier, Burlington

Benkhelil J (1989) The origin and evolution of the Cretaceous Benue Trough (Nigeria). J Afr Earth Sci 8:251-282

Bustin RM, Cameron A, Grieve D, Kalkreuth W (1985) Coal petrology: its principles, methods, and applications. Geological Association of Canada St. John's, Newfoundland

Chaudhuri SG, Choudhury N, Chatterjee CN, Mukherjee AK (2001) Application of main petrographic study in the prospecting of coal bed methane - an appraisal. In: Price coal Bed Methane prospects and potentialities, South Asian Association. Economic Geology, pp 110-116

Chukwu M, Folayan C, Pam G, Obada D (2016) Characterization of some Nigerian coals for power generation. J Combust 2016:1-11

Diessel CFK (1992) Coal-bearing depositional systems. Springer, Berlin

Fatoye FB, Gideon YB (2013) Geology and mineral resources of the Lower Benue Trough, Nigeria. Adv Appl Sci Res 4(6):21-28

Gangadharan GK, Ramteke CP, Chaudhuri SN (2019) Petrographic studies to delineate suitable coal seams for coal liquefaction and their palaeo-environmental analysis: a case study from the Ib river and Mand-Raigarh coalfields of the Mahanadi valley coalfields, India. J Earth Syst Sci 128:165

Georgakopoulos A, Iordanidis A, Kapina V (2003) Study of low-rank Greek coals using FTIR spectroscopy. Energy Sources 25:9951005

Grady WC, Eble CF, Neuzil SG (1993) Brown coal maceral distributions in a modern domed tropical Indonesian peat and a comparison with maceral distributions in Middle Pennsylvanianage Appalachian bituminous coal beds. Geol Soc Am Spec Pap 286:63-82

Hower JC, Graham UM, Wong AS, Robertson JD, Haeberlin BO, Thomas GA, Schram WH (1998) Influence of flue-gas desulfurization systems on coal combustion by-product quality at Kentucky power stations burning high-sulfur coal. Waste Manag 17:523-533

IEA-OECD (2002) Coal in the energy supply of India. International Energy Agency (IEA), Paris

Iwayemi A (2008) Investment in electricity generation and transmission in Nigeria: issues and options. Int Assoc Energy Econ 7:3742 
Jauro A, Chukwu C (2011) Production of formed coke from Nigerian coals. Pet Coal 53:22-25

Jauro A, Obaje N, Agho M, Abubakar M, Tukur A (2007) Organic geochemistry of Cretaceous Lamza and Chikila Coals, upper Benue trough, Nigeria. Fuel 86:520-532

Jauro A, Chigozie A, Nasirudeen M (2008a) Determination of selected metals in coal samples from Lafia-Obi and Chikila. Sci World J 3:79-81

Jauro A, Agho MO, Abayeh OJ, Obaje NG, Abubakar MB (2008b) Petrographic studies and coking properties of Lamza, Chikila and Lafia-Obi coals of the Benue Trough. J Min Geol 44(1):3743

Kanagawa M, Nakata T (2008) Assessment of access to electricity and the socio-economic impacts in rural areas of developing countries. Energy Policy 36:2016-2029

Kettanah YA, Eble CF (2017) Petrology, mineralogy and geochemistry of Hemrin Coal Seam, Hemrin South Mountain, Northern Iraq. Int J Coal Geol 181:39-59

Khan I, Jack MW, Stephenson J (2018) Analysis of greenhouse gas emissions in electricity systems using time-varying carbon intensity. J Clean Prod 184:1091-1101

Kieseler S, Neubauer Y, Zobel N (2013) Ultimate and proximate correlations for estimating the higher heating value of hydrothermal solids. Energy Fuels 27:908-918

King L (1950) Speculations upon the outline and mode of distribution of the Gondwanaland. Geol Mag 87:352-359

McGlade C, Ekins P (2015) The geographical distribution of fossil fuels unused when limiting global warming to $2{ }^{\circ} \mathrm{C}$. Nature 517:187

Meinshausen M et al (2009) Greenhouse-gas emission targets for limiting global warming to $2{ }^{\circ} \mathrm{C}$. Nature $458: 1158$

Nasirudeen M, Jauro A (2011) Quality of some Nigerian coals as blending stock in metallurgical coke production. J Miner Mater Charact Eng 10:101

Nyakuma BB, Oladokun O, Jauro A, Nyakuma DD (2017) Evaluating the energy recovery potential of Nigerian coals under nonisothermal thermogravimetry. IOP Conf Ser Mater Sci Eng 217:012013

Nyakuma B, Jauro A, Oladokun O, Bello A, Alkali H, Modibo M, Abba M (2018) Physicochemical, mineralogical, and thermogravimetric properties of newly discovered Nigerian Coals. Pet Coal 60:641-649

Obaje NG, Ligouis B, Abaa SI (1994) Petrographic composition and depositional environments of Cretaceous coals and coal measures in the Middle Benue Trough of Nigeria. Int J Coal Geol 26:233-260

Obaje NG, Pearson MJ, Suh CE, Dada SS (1999) Organic geochemical evaluation of the source rock potential of Late Cretaceous sediments in the Upper Benue Trough of Nigeria. J Min Geol 35 (2): $137-152$

Obaje N, Wehner H, Scheeder G, Abubakar M, Jauro A (2004) Hydrocarbon prospectivity of Nigeria's inland basins: from the viewpoint of organic geochemistry and organic petrology. AAPG Bull 88:325-353

Oboirien B, North B, Obayopo S, Odusote J, Sadiku E (2018) Analysis of clean coal technology in Nigeria for energy generation. Energy Strategy Rev 20:64-70

Offodile ME (1976) The geology of the Middle Benue, Nigeria [stratigraphy, palaeontology, hydrography]. Uppsala University, Uppsala

Offodile M (1980) A mineral survey of the Cretaceous of the Benue Valley, Nigeria. Cretac Res 1:101-124

Ogala JE (2018) Geochemistry of Coal and Coal Bearing Strata from the Upper Cretaceous Mamu Formation, Southeastern Nigeria: implications for Paleoredox History. FUW Trends Sci Technol J 3(2B):787-796
Ogala J, Siavalas G, Christanis K (2012) Coal petrography, mineralogy and geochemistry of lignite samples from the OgwashiAsaba Formation, Nigeria. J Afr Earth Sci 66:35-45

Ogungbesan GO, Akaegbobi IM (2011) Petrography and geochemistry of Turonian Eze-Aku Sandstone Ridges, Lower Benue Trough, Nigeria implication for provenance and tectonic settings. Ife J Sci 13(2):263-277

Ohimain EI (2014) Can Nigeria generate $30 \%$ of her electricity from coal. Int J Energy Power Eng 3:28-37

Olade MA (1975) Evolution of Nigeria Benue trough (Aulacogen) a tectonic model. Geol Mag 112(6):572-582

Olajire A, Ameen A, Abdul-Hammed M, Adekola F (2007) Occurrence and distribution of metals and porphyrins in Nigerian coal minerals. J Fuel Chem Technol 35:641-647

Oodo O, Zou J (2009) Prospects of a 100 MW coal-fired power plant in Benue State of Nigeria Electrical Engineering Department. Dalian University of Technology, China

Petters SW (1982) Central west African Cretaceous-Tertiary benthic foraminifera and stratigraphy. Palaeontogr Abt 179:1-104

Rajak PK, Singh VK, Singh PK (2019) Distribution of Inertinites in the early paleogene lignites of Western India: on the possibility of wildfire activities. J Geol Soc India 93:523-532

Ryemshak SA, Jauro A (2013) Proximate analysis, rheological properties and technological applications of some Nigerian coals. Int J Ind Chem 4:7

Sambo A (2009) Prospect of coal for power generation in Nigeria. In: A paper presented at the International workshop for the promotion of coal for power generation, pp 27-28

Scott AC (1998) The legacy of Charles Lyell: advances in our knowledge of coal and coal-bearing strata. Geolo Soc Lond Spec Publ 143:243-260

Shearer JC, Clarkson BR (1998) Whangamarino wetland: effects of lowered river levels on peat and vegetation. Int Peat J 8:52-65

Singh PK, Singh GP, Singh MP, Naik AS (2013) The petrology of coals from the Rampur Seam-IV and the Lajkura Seam, Ib River Coalfield, Mahanadi Valley, Orissa, India. Energy Sources A Recovery Util Environ Eff 35(18):1681-1690. https://doi.org/10. 1080/15567031003663158

Singh AL, Singh PK, Kumar A, Singh MP (2015) Demineralization of Rajmahal Gondwana coals by bacteria: revelations from X-ray diffraction (XRD) and Fourier transform infra-red (FTIR) studies. Energy Explor Exploit 33(5):755-767

Sonibare OO, Adedosu T, Ekundayo AO, Jarvie D (2008) Hydrocarbon potential and organic geochemistry of coals from Benue Trough, Nigeria. J Appl Sci Res 4(11):1511-1520

Sonibare OO, Haeger T, Foley SF (2010) Structural characterization of Nigerian coals by X-ray diffraction, Raman and FTIR spectroscopy. Energy 35:5347-5353

Speight JG (2012) The chemistry and technology of coal. Chemical industries, 3rd edn. CRC Press, Boca Raton

Vassilev SV, Vassileva CG, Vassilev VS (2015) Advantages and disadvantages of composition and properties of biomass in comparison with coal: an overview. Fuel 158:330-350

Vincent-Akpu I (2012) Renewable energy potentials in Nigeria. Paper presented at the 32nd annual meeting of the international association for impact assessment, Centro de Congresso da Alfândega Porto, Portugal, 27 May-1 June 2012

Whiteman AJ (1982) Nigeria; its petroleum geology, resources and potentials. Graham and Trotman, London, 394p

Yandoka BMS, Abdullah WH, Abubakar M, Hakimi MH, Jauro A, Adegoke AK (2016) Organic geochemical characterisation of shallow marine Cretaceous formations from Yola Sub-basin, Northern Benue Trough, NE Nigeria. J Afr Earth Sci 117:235-251

Zhang H, Gao E, Zhang X (2015) Comprehensive study on bituminous coal oxidation by TGA-DTA-FTIR experiment. J Power Technol 95(3):167-174 